\title{
Innovative and Sustainable Technologies to Enhance the Oxidative Stability of Vegetable Oils
}

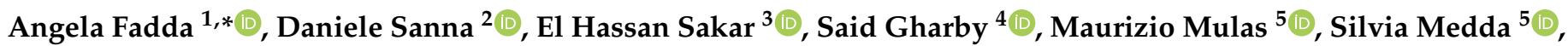 \\ Nese Sahin Yesilcubuk ${ }^{6}$, Asli Can Karaca ${ }^{6}{ }^{\circ}$, Celale Kirkin Gozukirmizi ${ }^{6}{ }^{\circ}$, Massimo Lucarini ${ }^{7}$,

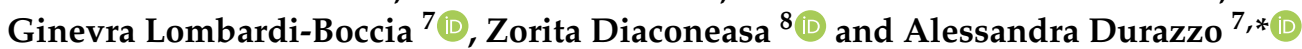

check for updates

Citation: Fadda, A.; Sanna, D.; Sakar, E.H.; Gharby, S.; Mulas, M.; Medda, S.; Yesilcubuk, N.S.; Karaca, A.C.; Gozukirmizi, C.K.; Lucarini, M.; et al. Innovative and Sustainable Technologies to Enhance the Oxidative Stability of Vegetable Oils. Sustainability 2022, 14, 849 https://doi.org/10.3390/su14020849 Academic Editor: Youngjoo Kwon Received: 17 December 2021 Accepted: 9 January 2022 Published: 12 January 2022 Publisher's Note: MDPI stays neutral with regard to jurisdictional claims in published maps and institutional affiliations.

Copyright: () 2022 by the authors Licensee MDPI, Basel, Switzerland. This article is an open access article distributed under the terms and conditions of the Creative Commons Attribution (CC BY) license (https:// creativecommons.org/licenses/by/ $4.0 /)$.
1 Institute of the Sciences of Food Production, National Research Council of Italy, Traversa la Crucca 3, 07100 Sassari, Italy

2 Institute of Biomolecular Chemistry, National Research Council of Italy, Traversa La Crucca 3, 07100 Sassari, Italy; daniele.sanna@cnr.it

3 Department of Biology, Faculty of Sciences of Tetuan, Abdelmalek Essaadi University, Mhannech II, Tetuan 93002, Morocco; sakar.statistics@gmail.com

4 Laboratory Biotechnology, Materials and Environment (LBME), Faculty Polydisciplinary of Taroudant, University Ibn Zohr, Agadir 80000, Morocco; s.gharby@yahoo.fr

5 Department of Agriculture, University of Sassari, Via E. Denicola 1, 07100 Sassari, Italy; mmulas@uniss.it (M.M.); smedda@uniss.it (S.M.)

6 Department of Food Engineering, Istanbul Technical University, Maslak, Istanbul 34469, Turkey; sahinnes@itu.edu.tr (N.S.Y.); cankaraca@itu.edu.tr (A.C.K.); kirkin@itu.edu.tr (C.K.G.)

7 CREA-Research Centre for Food and Nutrition, Via Ardeatina 546, 00178 Rome, Italy; massimo.lucarini@crea.gov.it (M.L.); g.lombardiboccia@crea.gov.it (G.L.-B.)

8 Department of Food Science, Faculty of Food Science and Technology, University of Agricultural Science and Veterinary Medicine, 400372 Cluj-Napoca, Romania; zorita.sconta@usamvcluj.ro

* Correspondence: angela.fadda@cnr.it (A.F.); alessandra.durazzo@crea.gov.it (A.D.)

\begin{abstract}
To meet consumers' demand for natural foods, edible oil producers and food processing industries are searching for alternatives to synthetic antioxidants to protect oils against oxidation. Antioxidant compounds extracted from different plant parts (e.g., flowers, leaves, roots, and seeds) or sourced from agri-food industries, including residues left after food processing, attract consumers for their health properties and natural origins. This review, starting from a literature research analysis, highlights the role of natural antioxidants in the protection of edible oils against oxidation, with an emphasis on the emerging and sustainable strategies to preserve oils against oxidative damage. Sustainability and health are the main concerns of food processing industries. In this context, the aim of this review is to highlight the emerging strategies for the enrichment of edible oils with biomolecules or extracts recovered from plant sources. The use of extracts obtained from vegetable wastes and by-products and the blending with oils extracted from various oil-bearing seeds is also pointed out as a sustainable approach. The safety concerns linked to the use of natural antioxidants for human health are also discussed. This review, using a multidisciplinary approach, provides an updated overview of the chemical, technological, sustainability, and safety aspects linked to oil protection.
\end{abstract}

Keywords: natural antioxidants; lipids oxidation; food waste; oil blending; sustainability; oxidative stability; peroxidation

\section{Introduction}

During storage, handling, or cooking, edible oils may undergo deterioration processes due to lipid oxidation. Oxidation is mainly responsible for the loss of oil quality, causing the decrease in an oil's nutritional value and giving rise to undesirable off-flavors, which make oils containing food less acceptable to consumers. Moreover, lipid oxidation produces some toxic by-products like reactive carbonyl compounds (RCCs), which could generate 
advanced lipid peroxidation end products (ALEs), which are potentially harmful to human health [1]. The extent of lipid oxidation depends upon the oil's internal factors, like the unsaturation degree, the presence of antioxidant compounds, or metals like copper and iron, and the oil's external factors, such as oxygen availability and temperature. The contact of oils with oxygen gives rise to chain reactions that progress faster with higher temperatures as well as with an increased unsaturation degree of the lipids.

Lipid peroxidation is a major concern for food industries due to the rising trend toward the replacement of hydrogenated oils containing saturated fatty acids (SFAs) with monounsaturated (MUFAs) and polyunsaturated fatty acids (PUFAs), which are considered healthier by consumers but are much more susceptible to oxidation than SFAs. In addition, oils rich in MUFAs and PUFAs, when exposed to deep frying or cooking temperatures, may develop RCCs, which originate ALEs, posing serious health risks. Even if the consumption of oils rich in MUFAs and PUFAs is strongly encouraged, these oils need to be "protected" before being used for cooking. Some oils (e.g., olive oil) are naturally protected by their high content of endogenous antioxidants (polyphenols and tocopherols), while some others (e.g., soybean, sunflower, and peanut oils), due to the refining process they undergo [2], need to be enriched with exogenous antioxidants during their production to make them more resistant to oxidation.

Thus far, the control of oxidation processes is achieved by synthetic antioxidants like butylated hydroxyanisole (BHA), butylated hydroxytoluene (BHT), tert-butylhydroquinone (TBHQ), and propyl gallate (PG), which are able to extend oils' storage time by delaying or hindering the degradation of lipids [3-5].

The safety concerns associated with the use of synthetic antioxidants and the consumers' increasing demand for natural food fostered the development of methods based on the employment of natural molecules to delay oil oxidation [6]. In this context, natural antioxidants have been suggested as an alternative to synthetic additives in the prevention of oil oxidative degradation. Plants are the main source of natural antioxidants, and the ability of plant antioxidants to protect oils from lipid degradation has been the topic of several investigations [7-14].

Make it green and make it healthy are the issues of the Next Generation EU program [15], which aims at making food production more sustainable for human health and for the environment. The strategy of the European commission in the future is to move toward a circular economy and sustainability, making better use of food waste, side streams, and by-products. Recent estimates report that about 88 million tons of food is wasted every year in Europe. Much of this waste comes from households, while food processing waste accounts for 30.6 million of tons annually, and fruits and vegetables contribute $35 \%$ [16]. These products still contain large amounts of bioactive compounds like flavonoids, anthocyanins, carotenoids, and phenolic acids, which can be valuable for the oils industry to enhance their oxidative stability [16].

Following the strategy adopted by the EU, this review focuses on the use of biomolecules and crude extracts obtained from food by-products and side streams to protect edible oils from oxidation. Starting from a qualitative and quantitative analysis of the literature published so far on the use of antioxidants to enhance oil oxidative stability, this work highlights the role of antioxidants in oils' oxidative stability, focusing on their mode of action as well as on the conventional and emerging analytical methodologies used to assess oxidative stability and antioxidants' efficacy. The role of natural antioxidants coming from food side streams and by-products and the innovative technologies recently developed, for oil enrichment, such as antioxidant encapsulation and blending with unconventional oils, are also discussed. Following a multidisciplinary approach, this review emphasizes the safety concerns linked to the use of natural antioxidants for human health. 


\section{Antioxidant, Oil Oxidative Stability, Waste, Biodiversity, and Sustainability: Literature Research Review}

To give a current snapshot of the interest raised in the international research context, a literature overview of the relationships among oxidative stability, oil, and antioxidants was performed on the Scopus database based on the following search string: ("oxidative stability*" AND "oil" ${ }^{* \prime}$ OR "antioxidant") (accessed on 24 October 2021). Bibliographic data (e.g., publication year, publication count, document type, countries or territories of origin, and institutions) were recorded. The functions of the Scopus web online platform named "Analyze" and "Create Citation Report" were utilized for carrying out basic analyses.

The search resulted in 2419 publications from 1953 to 2022. The most cited paper (1043 times) was that of Choe and Min [17], published in 2006 in Comprehensive Reviews in Food Science and Food Safety, addressing the mechanisms and factors behind edible oil oxidation.

The most productive author was Decker, E.A. with 48 documents. His most cited paper (336 times) dealt with lipid oxidation in corn oil-in-water emulsions stabilized by casein, whey protein isolate, and soy protein isolate [18]. Among the most cited works, the work of Faraji et al. [19] described the role of continuous phase protein in the oxidative stability of fish oil-in-water emulsions. Another one is focused on the antioxidant activity of cysteine, tryptophan, and methionine residues in continuous phase $\beta$-lactoglobulin in oil-in-water emulsions [20]. Figures 1 and 2 report the most productive countries or territories and institutions, respectively. Regarding countries and territories, the United States $(n=353)$ was the most productive country, followed by China $(n=256)$ and Brazil $(n=249)$. The main keywords covered for documents reported from the United States were antioxidant(s), oxidation, oxidative stability, chemistry, lipid oxidation, oxidation inhibition, and emulsion(s).

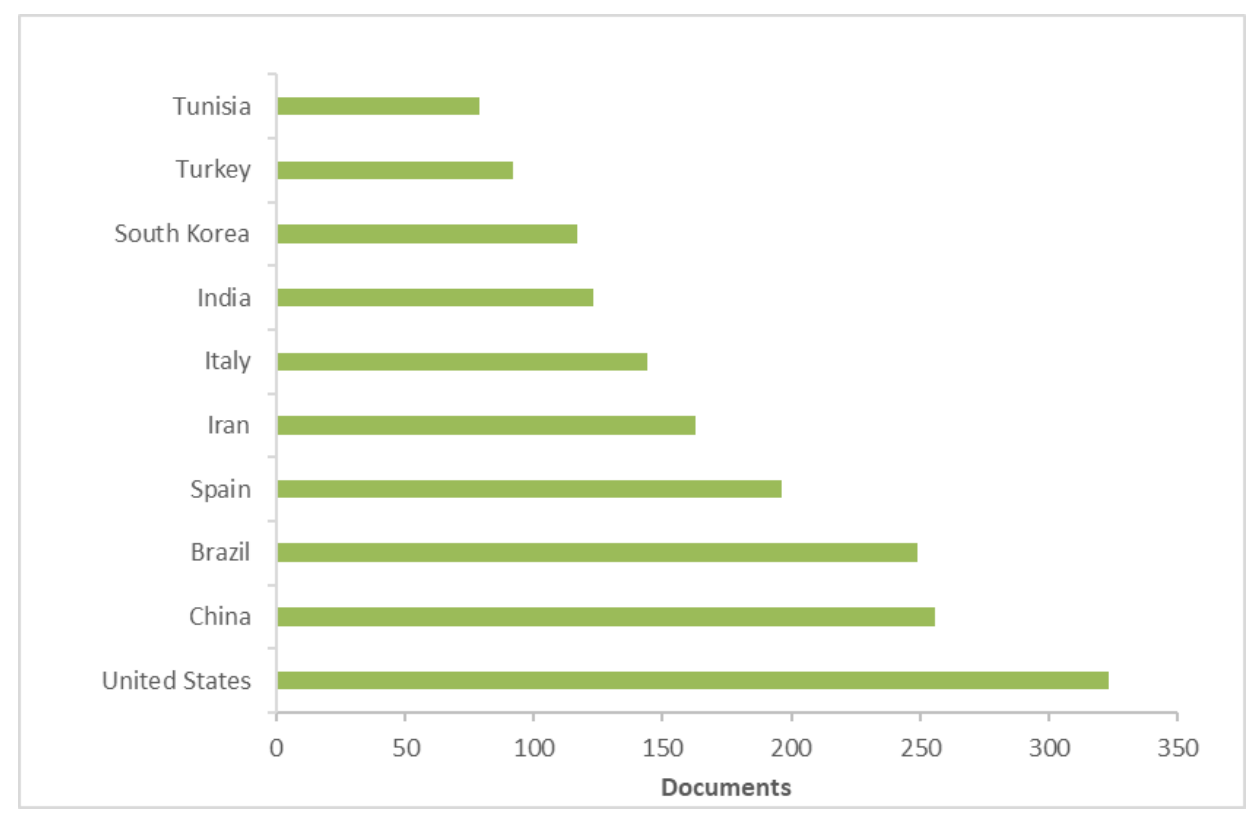

Figure 1. Most productive countries and territories (based on data from Scopus).

The most productive institution was the University of Massachusetts Amherst with 59 documents. All the top 10 institutions contributed at least 33 publications or more. The most cited paper was the paper of $\mathrm{Hu}$, McClements, and Decker [18], which was previously described, whereas the most recent work by Inchingolo et al. [21] described the ability of sodium dodecyl sulfate (SDS) micelles to increase the antioxidant activity of $\alpha$-tocopherol. 


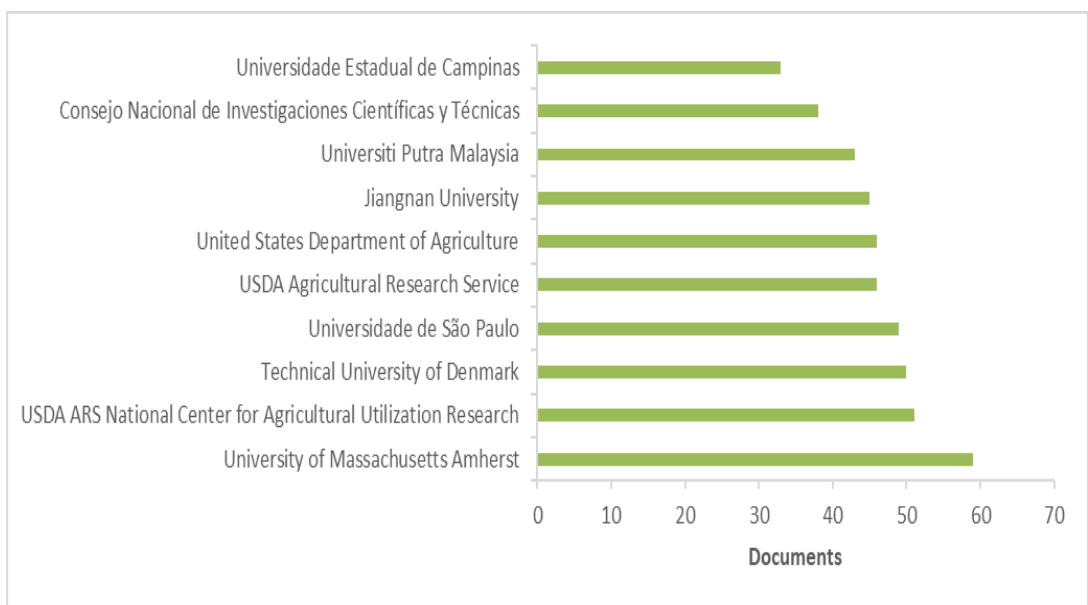

Figure 2. Most productive institutions (based on data from Scopus).

The search string TITLE-ABS-KEY ("oxidative stability" AND "oil" OR "antioxidant" AND "waste*" OR "by-product" OR "byproduct*") was also used to address the literature review search toward the utilization of waste and by-products. The search returned 172 publications covering the period from 1989 to 2021. "Full records and cited references" were exported to VOSviewer software (version 1.6.16, www.vosviewer.com, accessed on 24 October 2021) for further bibliometric study and additional processing. The VOS viewer software analyzes the terms or words used in the titles and abstracts of publications by breaking down the paragraphs into words and phrases, linking them with the citation data of the publications, and visualizing the results in the form of a bubble map by using a term map with the default settings [22-24].

The most cited paper (238 times) addressed the radical scavenging activity of black cumin (Nigella sativa L.), coriander (Coriandrum sativum L.), and niger (Guizotia abyssinica Cass.) crude seed oils and oil fractions [25]. Then, the paper of Fernández-Bolaños et al. [26] (160 times) dealt with the production in large quantities of highly purified hydroxytyrosol from the liquid-solid waste of two-phase olive oil processing or "alperujo". Iqbal, Haleem, Akhtar, Zia-ul-Haq, and Akbar [14] (138 times) described the efficiency of pomegranate peel extracts in the stabilization of sunflower oil under accelerated conditions.

A total of 105 terms were identified and visualized as a term map (Figure 3). The top recurring terms on oxidative stability, oil, antioxidant and waste, and by-product and byproduct research are the following: antioxidant(s), oxidative stability, chemistry, oxidation, fatty acids, oxidation-reduction, oxidation-reduction reaction, phenols, oils and fats, fruits, plant extract(s), antioxidant activity, olive oil, vegetable oil, plant oils, and biodiesel.

When narrowing the inquiry considering the sustainability and circular economy by using the search string TITLE-ABS-KEY: ("oxidative stability*" AND "oil" OR "antioxidant" AND "waste*" OR "by-product" OR "byproduct*" AND "sustainability" OR "circular economy", the search returned eight publications. Among the "Review" category, Difonzo et al. [27] described the functional compounds from olive pomace to obtain high added value foods. On the other hand, Blasi and Cossignani [7] gave an overview of natural extracts with antioxidant activity for the improvement of the oxidative stability and shelf life of edible oils, highlighting new approaches in the field of health-promoting foods. Angelovič et al. [28] focused on the review of the oxidative stability of fatty acid alkyl esters.

Among the "Article" category, Cisneros-Yupanqui et al. [29] gave a preliminary characterization of wastes from the rapeseed and sunflower protein isolation process and their valorization in delaying oil oxidation. The rapeseed and sunflower ethanol wash solutes showed great potential, and they could be used as a source of natural antioxidants in the field of the food industry, replacing the synthetic ones and promoting the circular economy since they are agro-food wastes. Luzi et al. [30] reported how hydroxytyrosol and 
oleuropein-enriched extracts from olive oil wastes and by-products act as active antioxidant ingredients for poly (vinyl alcohol)-based films.

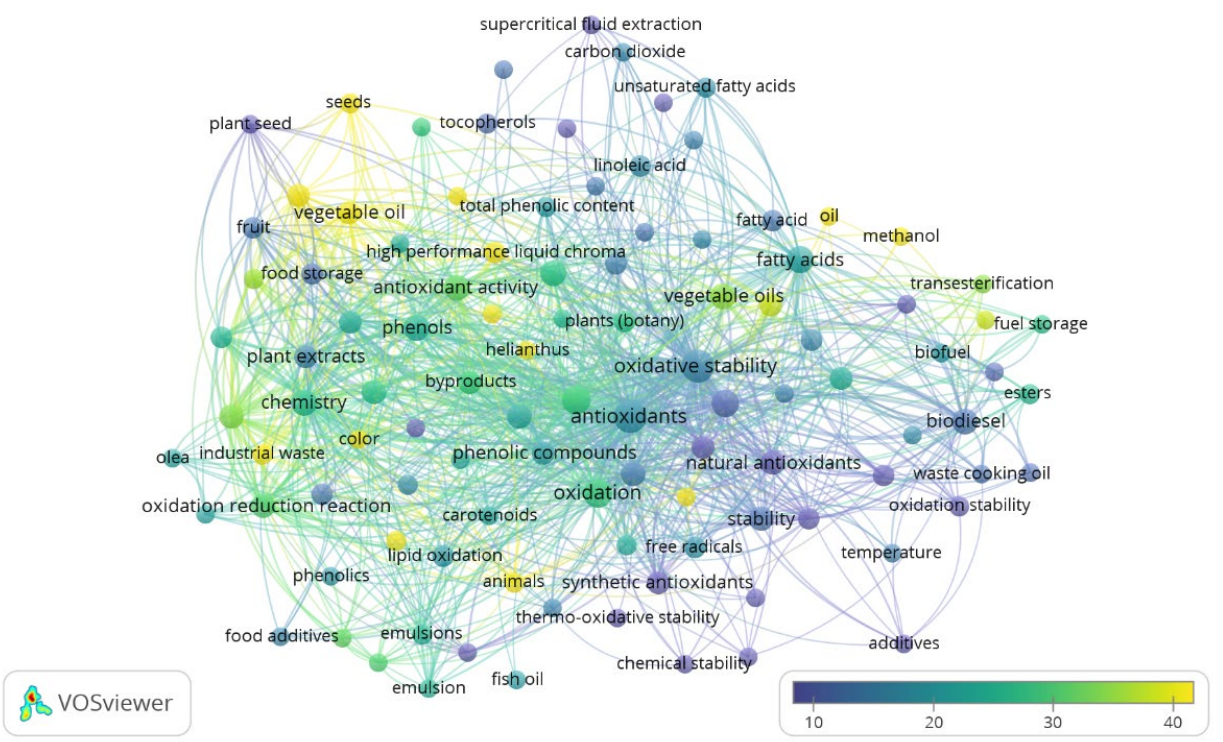

Figure 3. Term map for the search for oxidative stability, oil, antioxidants, and waste and byproduct publications. Bubble size indicates the number of publications. Bubble color represents the citations per publication (CPP). Two bubbles are closer to each other if the terms co-appeared more frequently (based on data from Scopus and elaborated by VOSviewer software, version 1.6.16, www.vosviewer.com, accessed on 24 October 2021).

On the other hand, the work of Drozłowska, Bartkowiak, Trocer, Kostek, TarnowieckaKuca, Bienkiewicz and Łopusiewicz [11] studied the influence of flaxseed oil cake extract on the oxidative stability of microencapsulated flaxseed oil in spray-dried powders. The flaxseed oil cake extract could be an adequate antioxidant dedicated to spray-dried emulsions, especially with a high content of flaxseed oil (20\%). Jolayemi et al. [31] studied the influence of free and encapsulated olive leaf phenolic extract on the storage stability of single- and double-emulsion salad dressings. Olive leaf extract encapsulation by the emulsification-internal gelation technique was effective in gradually releasing polyphenols during salad dressing storage, thus increasing the product's protection toward oxidation phenomena.

Branciari et al. [32] studied the oxidative status and presence of bioactive compounds in meat from chickens fed polyphenols extracted from olive oil industry waste. The semi-solid olive cake, known as "paté", positively affected the antioxidant status and the oxidative stability of the meat.

\section{Oils and Oxidative Stability}

\subsection{Oils: Classification, Properties, and Trends}

The production and consumption of oils and fats are mainly based on 17 commodities: 4 of animal origins and 13 of plant origins. Fats and oils of animal origins consist of tallow, lard, fish oil, and milk fat (butter). Vegetable origin oils are generally produced from the seeds or beans of plants such as palm, soybean, rapeseed, sunflower, coconut, olive, linseed, castor, sesame, peanut, cotton, and corn [33]. Palm oil, soybean oil, rapeseed oil, and sunflower oil are the most widely used major vegetable oils [34,35]. The saturated fatty acid content of most vegetable oils is less than $25 \%$ of the total fatty acids [36]. However, palm, palm kernel, and coconut oils are reported to have a higher content of saturated fatty acids, being about $49 \%, 80 \%$, and $90 \%$, respectively. The rest of the fatty acid composition consists of mono- and poly-unsaturated fatty acids, dominantly oleic (18:1) and linoleic acid (18:2) [36]. 
Palm oil is the most frequently used edible oil in the world [37]. Two types of oils with different fatty acid compositions can be obtained from palm fruit: palm oil and palm kernel oil [38]. The former is extracted from the mesocarp (rich in palmitic acid and oleic acid), and the latter is extracted from the kernel (rich in lauric acid) [37].

Olive oil is among the most popular gourmet and health-promoting specialty oils, and it is produced predominantly in the Mediterranean region [39]. Adherence to the Mediterranean diet, in which olive oil is a staple ingredient consumed in high amounts, is reported to be associated with various health benefits including a reduction in mortality due to coronary heart diseases [40].

Today, due to the increasing health awareness of individuals and rising living standards, eating habits are also changing. Heart diseases and cancer, which are closely related to diet, especially the quality and amount of dietary fat, are major causes of death in developed societies $[41,42]$. The functional properties of vegetable oils are mainly due to their fatty acid compositions (essential fatty acids such as $\omega-3$ and $\omega-6$ and the $\omega-3: \omega-6$ ratio) and bioactive components (e.g., tocopherols, sterols, squalenes, carotenoids, antioxidants, and phenolics).

In recent years, the interest in natural and reliable oils have been increasing. Therefore, consumer preferences have changed rapidly from refined oils toward virgin oils due to the increasing awareness of healthy nutrition. Consumers demand foods that are proven to have positive effects on health and contain health-promoting constituents. To meet consumers' demands, the bulk production of virgin oils should be accomplished from oilseeds or fruits at reasonable prices. For this purpose, there are major challenges that have to be addressed, including sustainable production of high-quality oil seed, the production of virgin oils with a higher yield, and higher bioactive components such as antioxidants.

\subsection{Oil's Oxidative Stability: Main Features, Mechanisms, and Analytycal Methods for Its Determination}

A vegetable oil's quality is defined by both its compositional and organoleptic properties. These also determine consumer acceptance and agro-industrial preferences. One of the main quality attributes in vegetable oils is their oxidative stability. Unfortunately, all vegetable oils can undergo a degradation phenomenon known as oxidation. This is a complex series of reactions leading to rancidity, smells, and off-flavors $[43,44]$. Likewise, a vegetable oil's shelf life depends on its oxidative stability $[45,46]$. It is noteworthy that during the oxidation process, some toxic compounds such as RCCs can result in advanced lipid peroxidation end products, which are potentially harmful to human health [47]. Many factors are involved in oil oxidation. The main important factors are the storage conditions, a high temperature, high oxygen availability, the level of polyunsaturated fatty acids, and their composition, as well as the presence of prooxidants such as chlorophylls, metal ions $\left(\mathrm{Fe}^{3+}\right.$ and $\left.\mathrm{Cu}^{2+}\right)$, and heavy metals $[17,48]$.

The oil oxidation reactions are explained by the conventional free radical chain phenomenon. This process begins with radical reactions on unsaturated fatty acids [49]. These reactions include three phases, namely initiation, propagation, and termination, involving several reactions and mechanisms that are well documented in the literature [50-53].

To assess an oil's oxidative stability, a set of routinely measured parameters is adopted. Among them, the peroxide value (PV) and $\mathrm{K}_{232}$ specific extinction coefficient, measured at $\lambda=232 \mathrm{~nm}$, are very important indicators of the degree of degradation of an oil at the initial stage (i.e., formation of primary oxidation products) [54]. Therefore, the determination of PV and $\mathrm{K}_{232}$ is a reliable method for predicting subsequent deterioration of an oil's organoleptic quality. However, an oil may be rancid or have mediocre organoleptic proprieties without having a high PV. In fact, the hydroperoxides or peroxides and conjugated dienes are unstable products, and they are quickly transformed into ketones and aldehydes as secondary oxidation products [55].

The content of the secondary oxidation products is usually evaluated by examining the p-anisidine value [56]. This is considered to be a more reliable indicator of oxidative 
rancidity compared with the PV [57]. The $\mathrm{K}_{270}$ specific extinction coefficient is another important index used to evaluate the secondary oxidation products. However, this parameter is not completely similar to the analysis of $\mathrm{p}$-anisidine, because the ketones are not detected in anisidine determination [58].

Likewise, a better picture of vegetable oil oxidation, the total oxidation (TOTOX), can be calculated. This index merges the PV (primary oxidation products) and p-anisidine value (secondary oxidation products). Total oxidation is better compared with the peroxide and $\mathrm{p}$-anisidine values since the hydroperoxides (peroxides) are unstable and do not offer a reliable picture for an oil's oxidative stability [59]. In general, a TOTOX less than 10 indicates better quality [59]. Other measurements such as the headspace volatiles (smell), free fatty acids (FFA), thiobarbituric acid value (TBA), iodine value (IV), the Rancimat test, and the Shaal Oven Test can also be tested for controlling the stages of the oxidative stability of vegetable oils $[46,60]$. The Rancimat test determines the resistance time of oil to oxidation, achieved via a conductimetric measurement [61-64]. Recently, electron paramagnetic resonance (EPR) spectroscopy coupled with the spin trapping techniques has gained great interest due to its reliability and specificity in the detection of the radicals produced during lipid oxidation. This technique has been used to determine the oxidative stability of food lipids, bulk oils, oil emulsions, or fried oils by measuring the resistance to the formation of radical species [65-67]. Peroxyl and alkoxyl radicals formed during oil oxidation are trapped by N-tert-butyl- $\alpha$-phenylnitrone (PBN), the most widely used open-chain nitrone spin trap, forming a PBN radical adduct detected by EPR. The presence of antioxidants hinders the propagation step of lipid peroxidation, slowing down the formation of the radical adducts which, being relatively stable, are easily detected by EPR in different vegetable oils [65,68-72].

\section{Focus on Synthetic and Natural Antioxidants for the Stabilization of Edible Oils}

Vegetable oils are widely used in food preparation. Their oxidative stability is a key quality parameter, which depends upon the balance of different intrinsic and extrinsic factors. The main important factors are fatty acid unsaturation, the composition of minor components, environment conditions, delivery techniques, and the use of antioxidants (Figure 4). Lipid oxidation leads to negative effects on both the food quality and human health. In such a context, minimizing oxidation and improving the oxidative stability of lipid-based products become imperative [73].

Vegetable oils are endowed with a wide variety of endogenous antioxidants (e.g., pigments, vitamins, tocols, and phenols). However, the use of exogenous antioxidants is widely practiced to improve oxidative stability. In this optic, synthetic antioxidants such as butylated hydroxyanisole (BHA), butylated hydroxytoluene (BHT), tert-butylhydroquinone (TBHQ), and propyl gallate (PG) are commercially used to extend an oil's shelf life by delaying or even hindering lipid degradation. Such molecules were considered "generally recognized as safe" (GRAS) [5]. However, some reports associated these molecules with health risks such as carcinogenesis, and their use was reduced [5,6]. Natural antioxidants are a good alternative to replace synthetic ones in the preservation of vegetable oils [3-5].

Natural extracts from various plant parts (e.g., peel, fruit, leaf, flower, and root) belonging to different herbs, agri-food residues, and by-products were investigated for their antioxidant power as well as their use for the enrichment of edible oils, with an emphasis on enhancing oxidative stability. Such natural extracts were proven to possess a wide range of bioactive compounds, which were identified as belonging mainly to carotenoids and phenols $[7,74]$. Promising results were obtained regarding the improvement of oxidative stability and shelf life of vegetable oils. The effect of natural extracts on an oil's oxidative stability will be discussed deeply in Section 5 of this review. With respect to the antioxidant activity of synthetic and natural additives, several mechanisms are involved. They act as free radical scavengers, inactivators of peroxides as well as other ROS, singlet oxygen quenchers, metal ion chelators, quenchers of secondary oxidation compounds, and inhibitors of pro-oxidative enzymes, among other functions [73]. According to these authors, 
antioxidants may be classified, based on their mode of action, into primary antioxidants, which break the oxidation chain reaction via scavenging free radical intermediates, and secondary antioxidants, which prevent or delay oxidation through the suppression of oxidation initiators, accelerators, or the regeneration of primary antioxidants.

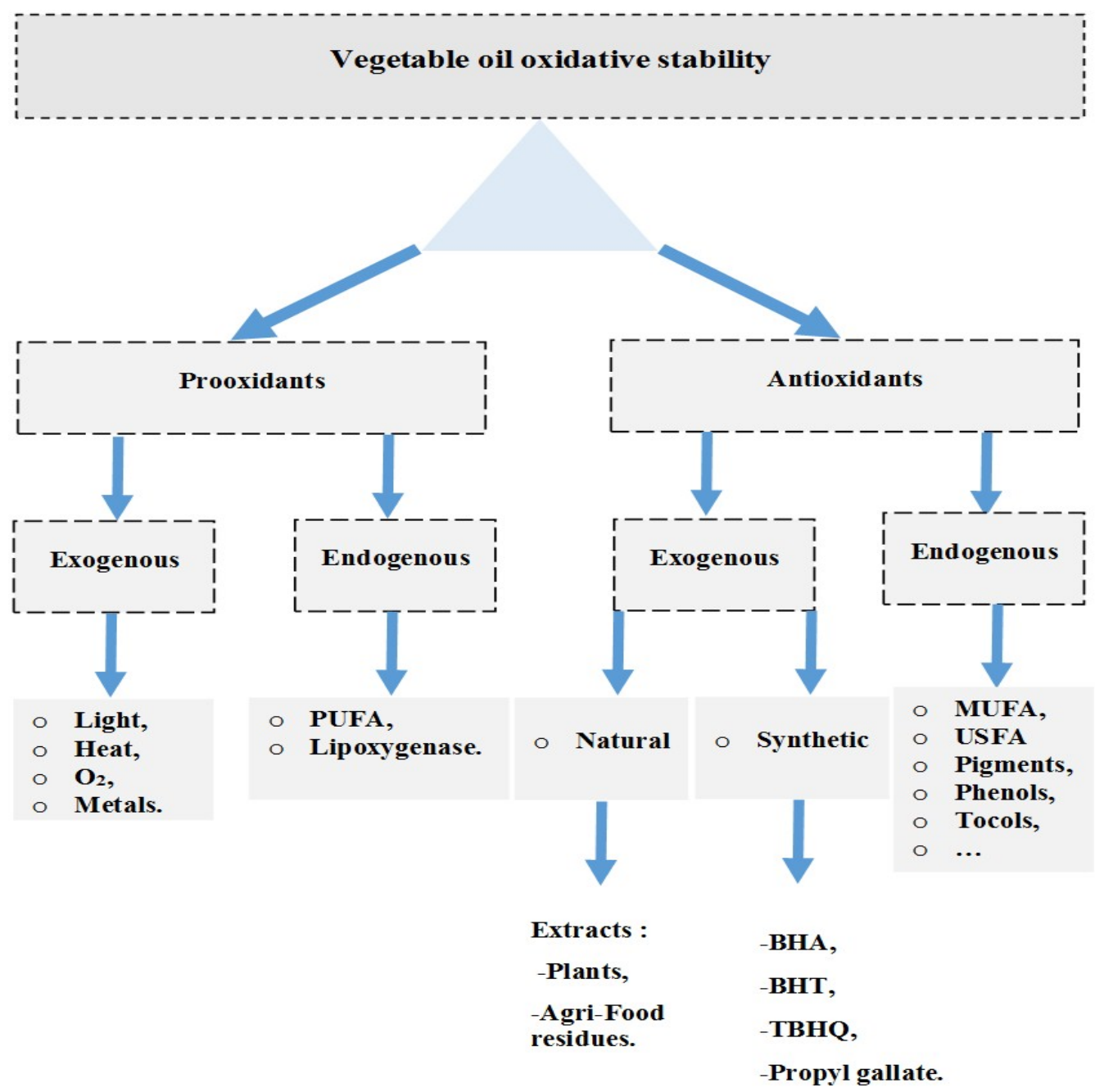

Figure 4. An overview of factors involved in vegetable oil oxidative stability.

\subsection{Synthetic and Natural Antioxidants}

The most commonly used synthetic antioxidants added to oils are BHA, BHT, TBHQ, and PG (Figure 5). The amount which can be added depends on national regulations, being around 100-200 $\mathrm{mg} \mathrm{kg}^{-1}[3,12,75-78]$. These compounds share the common structural feature of having at least one phenolic group. TBHQ and PG are more effective than BHT and BHA because they can be oxidized to semiquinones and quinones, but PG can also chelate redox active metal ions like iron(II/III).

Redox active transition metal ions $\left(\mathrm{Fe}^{\mathrm{II}} / \mathrm{Fe}^{\mathrm{III}}\right.$ or $\left.\mathrm{Cu}^{\mathrm{I}} / \mathrm{Cu}^{\mathrm{II}}\right)$ can influence the initiation step of a lipid peroxidation reaction. In fact, if these metal ions are present in reduced form $\left(\mathrm{Fe}^{\mathrm{II}}\right.$ or $\left.\mathrm{Cu}^{\mathrm{I}}\right)$, they can react with peroxides, generating hydroxyl radicals $\left({ }^{\bullet} \mathrm{OH}\right)$ with a Fenton reaction, which in their turn can start new radical chain reactions. In the literature, it has been reported that chelating agents exert their antioxidant activity by blocking the cycling of redox-active metal ions between the two redox states (i.e., $\mathrm{Fe}^{\mathrm{II}} / \mathrm{Fe}^{\mathrm{III}}$ ) [79]. This is not strictly true because the chelating ligands can coordinate both the oxidation states of the metal ions. What is really changed is the redox potential of the couple $\mathrm{Fe}^{\mathrm{II}} / \mathrm{Fe}^{\mathrm{III}}$ [80]. If the chelating ligands stabilize the oxidized form $\left(\mathrm{Fe}^{\mathrm{III}}\right), \mathrm{Fe}^{\mathrm{II}}$ will oxidize more easily to $\mathrm{Fe}^{\mathrm{III}}$, its concentration will be decreased, and this will not be able to give the Fenton reaction, thus 
preventing the start of new radical chain reactions [81]. The more active natural or synthetic antioxidants have in their structure di- or tri-hydroxybenzene (o-catechol) moieties, and these are strong chelating agents with a high affinity for $\mathrm{Fe}^{\mathrm{III}}$. When these ligand molecules are present in oils together with trace amounts of metal ions (Fe or $\mathrm{Cu}$ ), the latter have more of a tendency to exist in oxidized form, thus preventing the Fenton reaction and therefore protecting oils from further oxidation.<smiles>COc1ccc(O)cc1C(C)(C)C</smiles>

Butylated hydroxyanisole (BHA)<smiles>COc1ccc(O)c(C(C)(C)C)c1</smiles>

Butylated hydroxytoluene tert-Butylhydroquinone (BHT)<smiles>CC(C)(C)c1cc(O)ccc1O</smiles>

(TBHQ)<smiles>CCCOC(=O)c1cc(O)c(O)c(O)c1</smiles>

Propyl gallate (PG)

Figure 5. Synthetic antioxidants.

The mechanism of action of antioxidants entails the formal abstraction of a hydrogen atom $\left(\mathrm{H}^{\bullet}\right)$ from the phenol group $(\mathrm{Ph}-\mathrm{OH})$ to form a phenoxyl radical $\left(\mathrm{Ph}-\mathrm{O}^{\bullet}\right)$, which being stabilized by resonance and/or sterically hindered is less reactive than the alkyl/peroxyl radicals involved in the lipid peroxidation chain reaction. In this way, the propagation step is hindered or slowed down, contributing to the increased oxidative stability of oils.

Natural and synthetic antioxidants, depending on their concentrations, can behave as, aside from beneficial antioxidants, pro-oxidants. This has been verified with purified olive oil (containing only triacylglycerols without mono- or di-acylglycerols or other minor components) containing 100,500, and $1000 \mathrm{ppm}$ of $\alpha$-tocopherol [82]. The greater protective effect against the formation of peroxides during storage at $40{ }^{\circ} \mathrm{C}$ was obtained with 100 ppm of tocopherol, while at a higher concentration, the protection decreased. This effect was due to the auto-oxidation of tocopherol, which generated free radicals that could start new chain reactions. Vegetable oils contain ca. 95\% of triacylglycerols, with some di- and mono-acylglycerols and free fatty acids. Some of the remaining 5\% comprises compounds that can be classified as antioxidants, like tocopherols, tocotrienols, and polyphenolic compounds [83]. Tocopherols and tocotrienols exist as four different compounds each, indicated by the letters $\alpha, \beta, \gamma$, and $\delta$ and differing by the number and position of methyl substituents on the chromane ring (Figure 6A). There is no agreement on the relative antioxidant activity of tocopherols in vitro [84]. The results depend on what is being measured. For example, $\gamma$ is more effective than $\alpha$ at trapping radical species because it has no substituent on $\mathrm{C}-5$, while if we consider the stability of the tocopherol radical, $\alpha$ is the more stable one, because all the $\mathrm{H}$ atoms in the aromatic ring are replaced by $\mathrm{CH}_{3}$ groups. The three methyl groups on the aromatic chromane ring stabilize the phenoxyl radical by inductive and steric effects. Olive oil contains tocopherols in the range $100-300 \mathrm{mg} \mathrm{kg}^{-1}$ [85], while sunflower oil contains between 440 and $1520 \mathrm{mg} \mathrm{kg}^{-1}$ [86]. The tocopherol contenet in argan oil can be up to $900 \mathrm{mg} \mathrm{kg}^{-1}$ and is never below $600 \mathrm{mg} \mathrm{kg}^{-1}$ [54].

Polyphenolics comprise a large variety of compounds, among which phenolic acids (o- and p-coumaric, vanillic, homovanillic, sinapic, syringic, p-hydroxybenzoic, p-hydroxyphenylacetic, ferulic acids, all containing only one phenolic $-\mathrm{OH}$ group and one or more $-\mathrm{OCH}_{3}$, as well as caffeic, protocatechuic, and gallic acids containing two or three adjacent $\mathrm{OH}$ groups), tyrosol, hydroxytyrosol, and their ester derivatives (oleuropein, ligstroside, oleacein, and oleocanthal).

Most of these compounds, as their names suggest, contain one or more phenolic groups, and when more than one is present, some can exist as $-\mathrm{OCH}_{3}$. These latter groups are less effective in comparison with phenolic $-\mathrm{OH}$ groups at scavenging radical species because they cannot donate a hydrogen atom to quench radical species, but they 
are effective at stabilizing the structure of phenoxyl radicals because they can delocalize the unpaired electron, thus contributing to decreasing their reactivity.

The content of polyphenolic compounds in olive oil is in the range of $100-300 \mathrm{mg} \mathrm{kg}^{-1}$ [85], while in sunflower oil it is much less $\left(0.178 \mathrm{mg} \mathrm{kg}^{-1}\right)$ [87].

The mechanism of action of polyphenolic compounds and tocopherols is analogous to that previously described for synthetic antioxidants, which is forming a relatively stable phenoxyl radical which can effectively block the propagation step of lipid peroxidation. Di- and tri-hydroxybenzenes are more effective because they can be oxidized to the corresponding o-semiquinones and o-quinones.

Other minor components include carotenes, which are a group of compounds containing the isoprene unit (Figure 6B). They contain a large number of conjugated double bonds and, after interacting with free radicals, form less reactive radical species stabilized by resonance. Moreover, they are good quenchers of singlet oxygen, which reacts with PUFA- and MUFA-generating peroxides [88].

A<smiles>Cc1c(C)c2c(c(C)c1O)CCC(CCC[C@H](C)CCC[C@H](C)CCCC(C)C)O2</smiles>

B
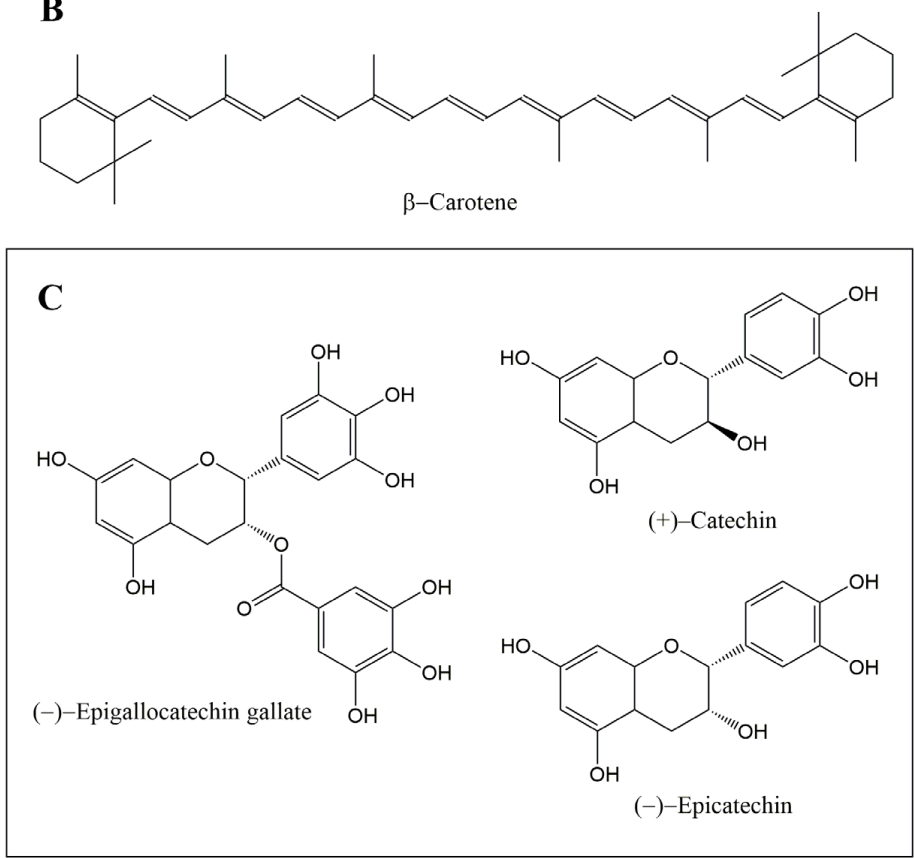

Figure 6. Chemical structures of natural antioxidants: $\alpha$-tocopherol (A), $\beta$-carotene (B), and main components of tea polyphenol palmitate $(\mathbf{C})$, where at least one of the $-\mathrm{OH}$ groups is present as an ester with palmitate $\left(-\mathrm{O}-\mathrm{CO}-\left(\mathrm{CH}_{2}\right)_{14} \mathrm{CH}_{3}\right)$ [89].

\subsection{New Sources of Antioxidants: Agri-Food Waste and By-Products in the Perspective of Biorefinery and a Circular Economy}

A great challenge is given by the reutilization of the large quantities of waste and byproducts produced every year in the processing of fruit and vegetables. A new goal of the circular bioeconomy and the biorefinery concept is represented by the "Universal Recovery Strategy" [90,91]. As reported by Lin et al. [92], for each type of food, different percentages of waste are produced along different stages of both food chain and industrial processing. In particular, by-products obtained from plant food processing can be considered a promising source of bioactive compounds, with a great range of applications in different fields (e.g., nutraceutical, cosmeceutical, and ingredients for high value food products [93]). 
Biorefinery represents an integrated approach and strategy to tackle food waste valorization in the perspective of a circular economy by addressing the agro-food chain and the lifestyle toward a "zero waste" model [94]. Sustainable food management is based on a circular economy and requires efforts and changes in agricultural and industrial organization [95].

\subsection{Antioxidants' Extraction Methods}

Nowadays, different extraction methodologies have been introduced, such as green and sustainable techniques for the separation of natural products from waste, in order to replace the conventional methods of extraction based on the use of organic solvents [96]. Examples of this include enzymatic treatment, microwave-assisted extraction, ultrasoundassisted extraction, supercritical and subcritical fluid extraction, and others.

For instance, Gligor et al. gave a comprehensive review of enzyme-assisted extractions of polyphenols. The use of specific enzymes or enzyme mixtures as well as the set-up of the process parameters (e.g., temperature, time, concentration, and $\mathrm{pH}$ ) are key elements [97].

Kumar et al. described the ultrasound-assisted extraction (UAE) of bioactive compounds from fruit and vegetable processing by-products [98]. Ultrasound waves, by inducing cavitation with erosion of the plant tissues, fragmentation of the cells, and the release of bioactive compounds, can increase the extraction yield with respect to conventional techniques [98,99]. Microwave-assisted extraction is described as an efficient method, with short extraction times, high extraction rates, selectivity, and yields, and low cost [100].

The very recent review of Villacis-Chiriboga [101] gives an overview of the applications and economic and environmental aspects of biorefinery via supercritical fluid extraction. The subcritical water extraction of natural products is currently described by Cheng et al. [102] under ecology, economy, and safety aspects. Its major advantage is that water is nontoxic, and so it is more suitable for the extraction of herbs, vegetables, and fruits.

A current and green alternative to study bioactive components in foods and food wastes is given by the combined use of spectroscopic techniques and chemometrics, which has the advantage of a simple sample preparation and extraction procedure and a short time for data collection and analysis [103,104].

Generally, the current approach is the application of sustainable and integrated methods to food wastes and by-products, particularly toward the construction of a new suitable and industrial platform under the perspective of the biorefinery approach [105-108].

\section{Enrichment of Edible Oils with Antioxidant Rich Extracts}

\subsection{Application and Beneficial Outcomes: Case Studies}

Because lipid peroxidation is a drawback for the food industry, some studies focused on finding solutions to overcome this issue (Figure 7). In this way, researchers put their efforts toward finding the best way to increase an oil's stability. Rubio et al. [109] revealed that although virgin olive oil has phenolic compounds in its composition, an enriched olive oil with thyme phenolic extract showed increased oxidative stability and also a higher level of bioactive compounds, such as flavonoids, which have the ability to promote human health. Furthermore, the resulting product comprises the requirements of functional food, which gives phenol extract enrichment relevant applicability regarding an oil's stability [109].

Suarez et al. [110] managed to develop three prototypes of enriched virgin olive oils with phenols extracted from olive cake, which was a by-product. Their results were promising from different points of view. First of all, their article shows that the oxidative stability was increased proportionally with the addition of phenolic extract from olive cake, and the quality parameters remained within the range that made them edible. Second of all, the stability of the phenolic compounds during digestion was higher than under normal conditions, which can be an important premise for future studies regarding the bioavailability and metabolism of phenols [110]. Further studies were made in order to improve 
the stabilty of the enriched olive oil and enhance the bioavailability of phenolic compounds, which are known to be susceptible to degradation throughout the gastrointestinal tract. Thus, the scientists tested the effects of lecithin as an emulsifier that could stabilize the phenols. The results showed that not only did the lecithin increase the stability levels of the compounds, but the shelf life of the oils was also extended, delaying the initiation of peroxidation, which was in line with the results of Delgado-Adamez et al. [111,112]. Moreover, the same team of researchers highlighted that a higher amount of phenolic compounds in olive oil could increase the overall bioavailability of these substances in an in vivo study, showing that the concentration in plasma was higher in the case of enriched olive oil compared with plain oil [113]

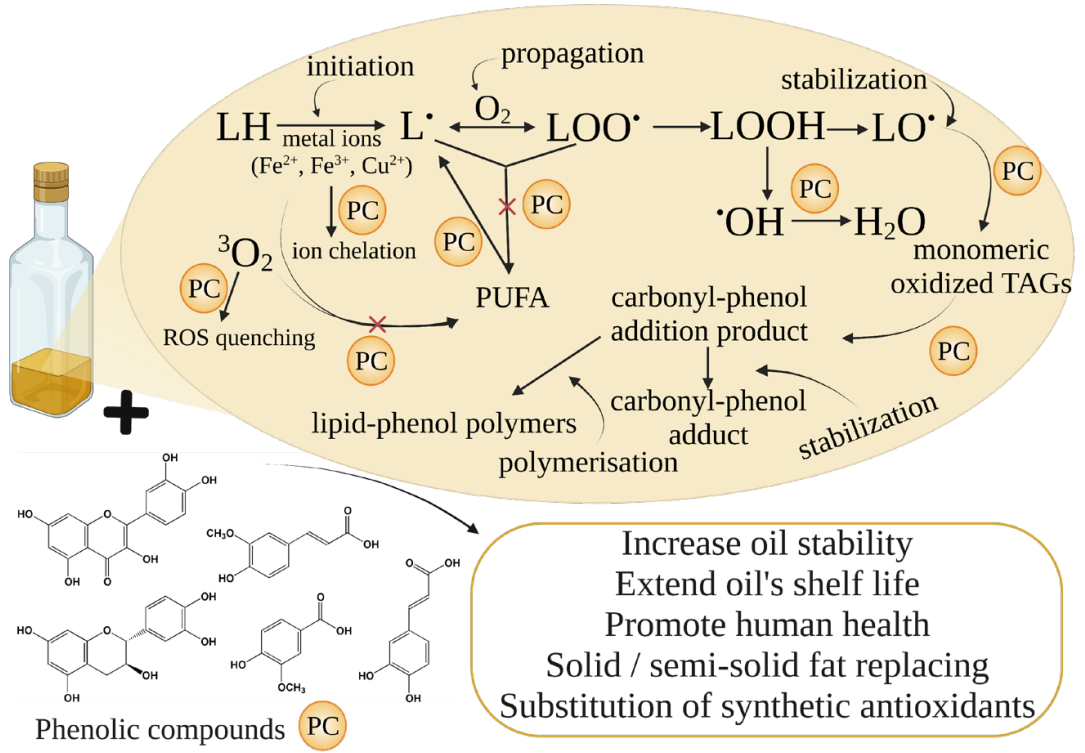

Figure 7. An overview of the oxidation reactions.

As is well known, today's trend is to substitute synthetic compounds from foods with natural substances that play the same role without changing the properties of the products. In this way, Chougui et al. [114] frameworked the industrial exploitation of byproducts of the Opuntia ficus-indica (prickly pear) extract in the substitution of Tocoblend (vitamin E), a synthetic antioxidant used as a preservative in margarine production. The results showed that the extract rich in phenolic compounds (1512.58 mg GAE/100g DM) managed to extend the shelf life of margarin without any effect on its physicochemical and microbiological properties. Although it was tested at different concentrations, the extract exerted better effects compared with vitamin E, even at half the concentration of the latest [114]. When analyzing this, an important application of enriched vegetable oils with phenolics is the ability to substitute synthetic compounds with natural ones obtained from by-products.

Another study focused its attention on the ability of tea polyphenol palmitate to stabilize camellia oil-based W/O (water-in-oil) emulsions (Figure 6C). Because of its rich content in unsaturated fatty acids (especially oleic acid) and other functional compounds, camellia oil was cataloged as a potential substitute for solid or semi-solid fats. The scientists used tea polyphenol palmitate to stabilize the emulsion and, in this way, proposed a method by which the fat could be replaced with a more stable and surfactant-free emulsion. Moreover, their final product had increased storage stability and a better freeze-thaw stability. Taking into consideration the visual appearace and the rheological characterization, it was proven that enriching a camellia oil-based emulsion with tea polyphenol palmitate can be a promising solid fat replacer and a better one compared with margarine because of its higher slip melting point (SMP) [115]. 
Sahin et al. [116] recently conducted a study regarding the enrichment of hazelnut oil with several polyphenols as an alternative approach to a novel functional food. The oil sample was supplemented with six compounds, among which gallic acid showed enhanced stability against oxidation three times greater than the pure sample itself. This study strengthened the premise that enriching edible oils with polyphenols increases oxidative stability [116].

Additionally, one study analyzed the effect of a phenolic extract obtained from walnut press cake on oxidative stability of walnut oil. The press cake is a valuable source of phenolic compounds which shows a reduction of the formation of oxidation products in the sample that contains it compared with the control. The results showed that $200 \mathrm{mg} / \mathrm{kg}$ of oil phenolic extract from a walnut press cake successfully stabilized the tested oil, making the enrichment a potential natural antioxidant alternative [117].

In 2021, Abenoza et al. [118] implemented a strategy to increase the shelf life of Empeltre virgin olive oil by incorporating flavoring agents rich in antioxidant compounds such as garlic and rosemary. The enrichment increased the total phenolic content, and as a consequence, the antioxidant capacity and oxidative stability were enhanced, especially when the incorporation was carried out during malaxation. From the sensory point of view, garlic aromatization achieved a better score compared with rosemary, which was more effective in increasing the phenolic content. Further studies are necessary in order to obtain the best flavoring agent, but it is important to obtain a high phenolic content in virgin olive oil, as European regulations recognized it as a related health claim [118].

Aside from improving the stability, nowadays, there is a growing interest in studying new formulations to also improve the functional properties of foods. Recently, many natural antioxidants have been obtained from agro-industrial waste and used in the food industry. Cocoa bean husk, which has long been considered a waste, showed in several studies its biological and potential health benefits due to its phenolic content, making it susceptible for incorporation in food products. The chosen product was extra virgin olive oil jam, as in its case, the prevention of oxidation of both phases is crucial, as is a heterogeneous matrix formed by oil and water. The study analyzed the efficiency of both encapsulated and non-encapsulated extract from cacao bean husk and observed that for foods with higher contents of oil, it would be recommended to not use encapsulation, and in the case of a higher aqueous content, encapsulation is more appropriate. The results showed that the enrichment improved the stability and antioxidant activity of the tested product [119].

Approaching the sustainability point of view, olive mill wastewater contains high amounts of phenols and their derivates, which are valuable, but its disposal is toxic, and it is difficult to biodegrade. In this way, the recovery of phenolic compounds represents a promising approach to obtaining suitable compounds for food enrichment. Romeo et al. [120] conducted a study aimed to evaluate the efficiency of the enrichment of sunflower oil with a phenolic extract from olive mill wastewater. In order to evaluate the resistance of oil to oxidation, the samples were subjected to a high oxidative stress environment, and increased stability was observed, which was associated with the addition of phenolic extract. Thus, the researchers successfully valorized a by-product from the oils industry by converting it from waste to resource [120].

Aside from the oil itself, there is also a focus on the prevention of oxidation in the case of blends. Edible oils such as olive, soybean, and rice bran oils are considered long-chain triacylglycerols (LCTs) and possess monounsaturated and polyunsaturated fatty acids with tocopherols, and their consumption requires several steps for digestion. The excess is likely to be stored as fat, causing different health-related issues. In order to reduce this risk, LCTs are blended with MCTs (oils with medium-chain fatty acids), which are rapidly digested, representing a quick source of energy. Thus, preventing the oxidation of edible oil blends was the purpose of More et al.'s [121] study. They incorporated moringa leaf extract and pomegranate peel extract in an edible oil blend, and the rate of oxidation was 
clearly retarded. They concluded that the obtained results were comparable or at times better than the effect of chemical antioxidants such as BHA and BHT [121].

As presented, the oxidative stability of edible oils can be enhanced using innovative and sustainable technologies, but aside from this principal aim, the enrichment gives the final product different beneficial properties, making it a functional food in most cases.

\subsection{Conventional and Emerging Strategies for Edible Oil Enrichment}

Spices, herbs, vegetables, and fruit are the main sources of natural antioxidants suggested as alternatives to synthetic molecules to counteract, hinder, or delay the peroxidation of edible oils. The comparison of natural antioxidants with BHT or BHA was the topic of several studies aimed at identifying the most effective and proper concentrations of natural extracts to maintain oil stability. The extracts obtained from vegetable sources are rich in flavonoids, phenolic acids, and tocopherols which, as highlighted in the previous paragraphs, play a role in oil's protection by slowing down the radical chain reactions occurring during lipid peroxidation.

Several papers reported the use of plant extracts as stabilizers of oils subjected to accelerated storage conditions or thermal treatments due to cooking. Rosemary, sage, oregano, olive leaves, pomegranate, mangosteen peels, and myrtle leaves are some examples of the crude extracts studied and proven to be as effective as BHT or BHA in protection against lipid peroxidation during the shelf life or frying. Mangosteen peel extracts at $200 \mathrm{ppm}$ delayed sunflower oil lipid oxidation like BHA [77]. Similarly, sesame cake extracts provided an effective inhibition of the thermal degradation of sunflower and soybean oils [122]. The enrichment of extra virgin olive oil (EVOO) with Myrtus communis L. phenolic compounds prevented the consumption of endogenous antioxidants in EVOO oil subjected to flame, oven, and microwave heating [78]. Recently, the methanolic extracts from the petals of 23 edible flower species have been used to enhance the oxidative stability of cold-pressed chia seed and flax oil. The flower species differed in their chemical compositions and their protective effects against oil oxidation, with the flowers with the highest concentration of flavonoids and carotenoids being the most effective. The authors associated the highest protection with the possible involvement of synergy between both flavonoids and tocopherols as well as tocopherols and carotenoids [123]. The effectiveness of the natural antioxidants on the oxidative stability of edible oils and the proper extracts' amounts have been recently reviewed $[2,7,124]$. In this paper, we focus on the emerging and sustainable strategies employed to meet the consumer's demand for natural and safe food additives. In addition, we target the technologies used to increase the solubility of the extracts in the oil's matrix.

In the last few decades, side streams and by-products from the food and beverage processing industries have become the most interesting sources of antioxidant compounds. Food wastes or food side streams and by-products, despite the processing they undergo, still retain a considerable amount of bioactive compounds, with health-promoting properties that may be also able to protect edible oils from oxidation.

Table 1 summarizes some of the studies dealing with oil's enrichment with extracts recovered from food wastes or by-products.

Carotenoids extracted from tomato peel by-product stabilized refined olive and sunflower oil against oxidation occurring during long storage periods at a concentration of 250 and $2000 \mathrm{\mu g} \mathrm{g}^{-1}$, respectively. The tomato by-products' protective effect was correlated with the amount of lycopene [125]. Pomegranate peel extract containing ellagic and gallic acid, punicalina, and punicalagina had a positive role in the stabilization of pomegranate seed oil stored under accelerated aging conditions. When applied at a concentration of $0.01 \%$, it effectively decreased the concentration of the secondary oxidation products, while when applied in combination with reduced doses of BHT, it inhibited the formation of the primary oxidation products without affecting the concentration of fatty acids [10]. Grape seed extract enhanced the oxidative stability of sunflower oil subjected to convective and microwave heating [126]. Flavonoids and flavanols recovered from sesame oil extraction by-products inhibited thermal-induced lipid peroxidation by inhibiting double-bond con- 
jugation and decreasing the loss of PUFA [122]. Water extracts obtained from olive mill wastewaters rich in hydroxytyrosol-, verbascoside-, and tyrosol-protected sunflower oil stored for 90 days at $25{ }^{\circ} \mathrm{C}$ [120].

The supplementation of sunflower oil with freeze-dried extracts (rich in pyrocathecol, rutin, and phenolic acids) obtained from blueberry processing by-products inhibited the formation of primary and secondary oxidation products in oils subjected to convective heating at $180{ }^{\circ} \mathrm{C}$ for $12 \mathrm{~h}$ to simulate frying conditions.

The analysis of the literature highlights the growing interest in the recovery of natural antioxidants from by-products and their use as a sustainable method for the protection of oils from oxidation. However, many times, the sustainability does not entail the whole extraction process. As can be observed in Table 1 (please see the type of extract column), green solvents or sustainable extraction methods have not always been used to recover natural antioxidants. In many cases methanol or hexane have been used, which cannot be considered sustainable solvents.

The stabilization of oils with phenolic compounds may be affected by several factors, like their low stability during processing, their poor solubility, and their interaction with fatty acids and with the minor components of the oil. The thermal stability and solubility are important characteristics to consider in the selection of the proper extract in oil oxidative stability. When added to bulk oils, most antioxidant extracts are poorly soluble, and being thermolabile in heated oils, they may lose their antioxidant activity. In a recent paper, Tinello and Lante [127] studied the protective effect of ginger and turmeric extracts on soybean oils stored for 28 days at $62{ }^{\circ} \mathrm{C}$, ascribing their strong effectiveness to their high solubility in oil and the resistance to thermal degradation. Phenolic compounds may have different thermal stabilities, depending on their chemical structure, with the cleavage of double covalent bonds being the main thermal degrading mechanism described [128]. For example, (-)-gallocatechin, the main component of litchi juice, disappeared after storage at $45{ }^{\circ} \mathrm{C}$ for $72 \mathrm{~h}$ [129]. Regarding the solubility of natural antioxidants added to the oils, it depends on the extraction solvent and on the phenolic composition of the extracts. Nwuha et al. [130] observed that the direct solubilization of a green tea extract in edible oils (oleic acid, rapeseed, sunflower, and coconut oils) was not successful at the applied temperatures $\left(20,40\right.$, and $\left.62^{\circ} \mathrm{C}\right)$, while a sunflower oil-ethanol mixture increased the extract solubility. It must be pointed out, however, that solubility, although very important, is not the only factor to consider. Mohanan et al. [131] compared the protective activity of natural compounds with a different degree of hydrophobicity in flaxseed oil oxidation. They observed that ascorbyl palmitate, a compound with intermediate polarity, was as effective as TBHQ, while tannic acid, a hydrophilic compound, and $\alpha$-tocopherol, which is highly soluble in oil, were not able to prevent oil oxidation. On the contrary, $\alpha$-tocopherol has shown pro-oxidant properties. This study highlights that aside from the natural antioxidant's polarity, the interaction with the minor compounds present in the oils determines the oxidative protection of the oils. Recently, the encapsulation technique has been suggested to protect the extracts during thermal treatments and to increase their solubility in oils [124]. Ethyl cellulose particles were loaded with tocopherol to stabilize this antioxidant at high temperatures. Ethyl cellulose particles with different viscosities were prepared, showing that the antioxidant effect increased with the viscosity [132]. 
Table 1. Extracts obtained from food wastes and by-products used to enhance the oxidative stability of edible oils.

\begin{tabular}{|c|c|c|c|c|c|c|}
\hline $\begin{array}{l}\text { Type of Waste or } \\
\text { By-Product }\end{array}$ & Type of Extract & $\begin{array}{l}\text { Extract Concentration } \\
\text { in the Oil }\end{array}$ & $\begin{array}{c}\text { Oil-Enriched and } \\
\text { Oxidative Treatment } \\
\text { Conditions }\end{array}$ & Analytical Approach & Main Results & References \\
\hline Olive mill wastewaters & Water extract (WE) & $\begin{array}{l}50 \text { mg hydroxytirosol } \\
\mathrm{L}^{-1} \text { of oil }\end{array}$ & $\begin{array}{l}\text { Sunflower oil (SFO) stored } \\
\text { for } 90 \text { days at } 10 \text { or } 25^{\circ} \mathrm{C}\end{array}$ & $\begin{array}{l}\text { Refractive index, } \\
\text { peroxide value, oxitest } \\
\text { oxidation test reactor, } \\
\text { DPPH, ABTS, } \\
\text { and ORAC }\end{array}$ & $\begin{array}{l}\text { WE increased the oxidative stability of } \\
\text { SFO and decreased the peroxide value }\end{array}$ & [120] \\
\hline $\begin{array}{l}\text { Tomato peel and seed } \\
\text { by-product }\end{array}$ & $\begin{array}{l}\text { Oleoresin extracted } \\
\text { with hexane }\end{array}$ & $\begin{array}{l}250,500,1000, \text { and } \\
2000 \mu \mathrm{g} \mathrm{g}^{-1} \text { of oil }\end{array}$ & $\begin{array}{l}\text { Refined olive oil (ROO) and } \\
\text { SFO } \\
\text { Storage for } 19 \text { weeks at } \\
50^{\circ} \mathrm{C}\end{array}$ & $\begin{array}{l}\text { Free acidity, peroxide } \\
\text { value, } \mathrm{k}_{232}, \mathrm{k}_{270}\end{array}$ & $\begin{array}{l}250 \text { and } 2000 \mu \mathrm{g} \mathrm{g}^{-1} \text { increased the } \\
\text { stability of ROO and SFO, } \\
\text { respectively }\end{array}$ & [125] \\
\hline Olive mill wastewaters & Water extract & $\begin{array}{l}500,1000,2000, \text { and } \\
3000 \mathrm{mg} \mathrm{L}^{-1} \text { of oil }\end{array}$ & $\begin{array}{l}\text { Extra-virgin and refined } \\
\text { kernel olive oil } \\
\text { Heating at } 100^{\circ} \mathrm{C} \text { for } 30 \mathrm{~min} \\
\text { Heating at } 160^{\circ} \mathrm{C} \text { for } 120 \mathrm{~min}\end{array}$ & $\begin{array}{l}\text { DPPH, peroxide value, } \\
\mathrm{k}_{270} \text {, Totox index }\end{array}$ & $\begin{array}{l}\text { Olive polyphenols were efficient } \\
\text { against oxidation of both oil types at } \\
1000-3000 \mathrm{mg} \mathrm{L}^{-1} \text {. Oils treated with } \\
\text { olive polyphenols and heated had } \\
\text { similar levels of PV than fresh oils. }\end{array}$ & [133] \\
\hline $\begin{array}{l}\text { Mango peel } \\
\text { by-product of mango } \\
\text { industrial processing }\end{array}$ & $\begin{array}{l}\text { supercritical } \mathrm{CO}_{2} \\
\text { extract }\end{array}$ & $\begin{array}{l}\text { 200, 500, and } 1000 \mathrm{mg} \\
\text { extract } \mathrm{kg}^{-1} \text { oil }\end{array}$ & Sunflower oil (SFO) & Rancimat method & $\begin{array}{l}\text { Mango peel extracts protected } \\
\text { sunflower oil against lipid oxidation } \\
\text { when evaluated between } 200 \text { and } \\
1000 \mathrm{mg} \text { extract } \mathrm{kg}^{-1} \text { oil }\end{array}$ & [134] \\
\hline $\begin{array}{l}\text { Sesame cake } \\
\text { by-product of oil } \\
\text { extraction }\end{array}$ & $\begin{array}{l}\text { Methanolic sesame } \\
\text { cake extract (SCE) }\end{array}$ & $\begin{array}{l}5,10,50,100, \text { and } \\
200 \mathrm{mg} \mathrm{kg}^{-1} \text { of oil }\end{array}$ & $\begin{array}{l}\text { SFO and soybean oil (SBO) } \\
\text { Stored for } 72 \text { h at } 70{ }^{\circ} \mathrm{C}\end{array}$ & $\begin{array}{l}\text { Peroxide value, } \\
p \text {-anisidine, } \mathrm{k}_{232}, \mathrm{k}_{270}, \\
\text { Schaal oven test }\end{array}$ & $\begin{array}{l}\text { SCE at } 200 \mathrm{mg} \mathrm{kg}^{-1} \text { inhibited SBO } \\
\text { oxidation in SFO SCE controlled } \\
\text { peroxide and } p \text {-anisidine formation }\end{array}$ & [122] \\
\hline $\begin{array}{l}\text { Olive mill wastewaters } \\
(\text { OMWW) and olive } \\
\text { pomace }(\mathrm{PO})\end{array}$ & Ethyl acetate extract & $1 \mathrm{mg} \mathrm{g}^{-1}$ of oil & $\begin{array}{l}\text { SBO subjected to accelerated } \\
\text { oxidation at } 60^{\circ} \mathrm{C} \text { for } \\
21 \text { days }\end{array}$ & $\begin{array}{l}\text { Schaal oven test, } \mathrm{k}_{232} \text {, } \\
\text { and } \mathrm{k}_{270}\end{array}$ & $\begin{array}{l}\text { Under accelerated oxidation } \\
\text { conditions, PO and OMWW extracts } \\
\text { were more effective than BHT. They } \\
\text { decreased } K_{232} \text { but had no effect } \\
\text { on } K_{270} \text {. }\end{array}$ & [135] \\
\hline $\begin{array}{l}\text { Blueberry juice } \\
\text { by-product (BBE) }\end{array}$ & $\begin{array}{l}\text { Hydro-alcoholic } \\
\text { extract, }\end{array}$ & $\begin{array}{l}200,500, \text { and } \\
800 \mathrm{mg} \mathrm{kg}^{-1} \text { of oil }\end{array}$ & $\begin{array}{l}\text { SFO } \\
\text { Simulated frying conditions } \\
\text { at } 180^{\circ} \mathrm{C} \text { for } 12 \mathrm{~h}\end{array}$ & $\begin{array}{l}\text { Peroxide value, } \\
p \text {-anisidine, Totox, } \\
\text { thiobarbituric acid test }\end{array}$ & $\begin{array}{l}\text { BBE } 800 \mathrm{mg} \mathrm{kg}^{-1} \text { inhibited the } \\
\text { formation of primary oxidation } \\
\text { products, BBE significantly inhibited } \\
\text { lipid thermo-oxydation, and BBE at } \\
500 \mathrm{mg} \mathrm{kg}^{-1} \text { was as effective as BHT } \\
200 \mathrm{ppm} \text {. }\end{array}$ & [3] \\
\hline
\end{tabular}


Table 1. Cont.

\begin{tabular}{|c|c|c|c|c|c|c|}
\hline $\begin{array}{l}\text { Type of Waste or } \\
\text { By-Product }\end{array}$ & Type of Extract & $\begin{array}{c}\text { Extract Concentration } \\
\text { in the Oil }\end{array}$ & $\begin{array}{c}\text { Oil-Enriched and } \\
\text { Oxidative Treatment } \\
\text { Conditions }\end{array}$ & Analytical Approach & Main Results & References \\
\hline Pumpkin peel & $\begin{array}{l}\text { Water extracts } \\
\text { obtained with } \\
\text { subcritical water } \\
\text { extraction (SWE) } \\
\text { Ethanol or water } \\
\text { extracts obtained with } \\
\text { supercritical } \mathrm{CO}_{2} \\
\text { extraction }(\mathrm{SFE})\end{array}$ & $400 \mathrm{mg} \mathrm{kg}^{-1}$ of oil & $\begin{array}{l}\text { Canola oil } \\
\text { Storage at } 30{ }^{\circ} \mathrm{C} \text { for } 60 \text { days }\end{array}$ & $\begin{array}{l}\text { Peroxide value, carbonyl } \\
\text { value, acid value }\end{array}$ & $\begin{array}{l}\text { Both SWE and SFE inhibited the } \\
\text { formation of peroxides and carbonyl } \\
\text { compounds during storage. } \\
\text { The mix of SFE and SWE was more } \\
\text { effective than the extracts alone. } \\
\text { Oils with SFE had lower acidity than } \\
\text { SWE-enriched oils. }\end{array}$ & [136] \\
\hline $\begin{array}{l}\text { Peel (AP) and seeds } \\
\text { (AS) from } \\
\text { avocado waste }\end{array}$ & $\begin{array}{l}\text { Freeze dried ethanolic } \\
\text { extract }\end{array}$ & $0.5 \%(w / w)$ & $\begin{array}{l}\text { Avocado oil and water } \\
\text { emulsions and } \\
\text { nanoemulsions stored for } \\
50 \text { days at room } \\
\text { temperature, oxidation was } \\
\text { induced by the addition of } \\
\mathrm{Fe}^{2+} \text { solution }\end{array}$ & $\begin{array}{l}\text { Peroxide value and } \\
\text { thiobarbituric acid test }\end{array}$ & $\begin{array}{l}\text { AP and AS had no effect on the } \\
\text { inhibition of peroxide production but } \\
\text { accelerated their degradation. Ap and } \\
\text { As limited the formation of secondary } \\
\text { oxidation products. }\end{array}$ & [137] \\
\hline
\end{tabular}


Nano-encapsulation of olive leaf extracts with pectin-WPC (wood plastic composite) increased the extracts' antioxidant activity and protected against the oxidation of soybean oil at a level comparable to that of TBHQ and higher than the extract alone, but it decreased the thermal stability of the extract [139]. Phospholipid-quercetin formulations increased the oxidative stability of camelina oil subjected to accelerated storage conditions [140]. The loading of $\alpha$-tocopherol in ethyl cellulose particles significantly improved the thermal stability of $\alpha$-tocopherol and hindered the oxidation of soybean oil heated at $180{ }^{\circ} \mathrm{C}$ for $25 \mathrm{~h}$ [141].

Methanolic extracts of Trifolium resupinatum were used in combination with lecithin to produce nanoliposomal structures which effectively protected the soybean oil against oxidation processes, as shown by the PV and TBA [142].

Other authors investigated the stabilization of fish oil-loaded electrosprayed capsules with dextran or glucose as the main biopolymer wall material, with an ethanol extract from the brown alga Fucus vesiculosus, or with a combination of $\delta$-tocopherol and rosemary extract [143]. The seaweed extract enhanced the stability of the fish oil when the main biopolymer was dextran, while $\delta$-tocopherol in combination with rosemary extract contained in glucose capsules stabilized the fish oil during 21 days of storage.

Extracts of green coffee fruits, either of the Arabica and Robusta variety, were microencapsulated with maltodextrin and gum Arabic and were tested to delay sunflower oil oxidation [144]. The microencapsulated extracts of green coffee fruits were more effective in delaying sunflower oil oxidation than the free extracts and BHT.

Microwave-assisted olive leaf extracts encapsulated by gum Arabic and maltodextrin were used to improve the thermal stability of soybean oil [145]. Encapsulation increased the thermal stability during 20 days of storage at $55^{\circ} \mathrm{C}$ in comparison with the free extracts, but the encapsulation decreased the antioxidant activity of the extracts.

Encapsulation has the advantage of improving the bioactivity and bioavailability of the extracts poorly soluble in oils, protecting them from thermal degradation. It also decreases possible pro-oxidant activities and provides their controlled release. However, as seen in these examples, the results depend on the treatment to which the oils are subjected, being very different when comparing prolonged storage with short heating at high temperatures.

\subsection{Safety Concerns Associated with the Use of Natural Antioxidants}

Studies have shown that phenols are a good choice when it comes to improving the quality of vegetable oils, managing the performance by increasing the shelf life, stability, and their nutritional qualities. Aside from being known as effective natural antioxidants, phenols managed to impress with their antimicrobial, anti-inflamatory, and anti-cancer properties, as demonstrated by numerous researchers who have been studying these compounds for several decades. However, in some cases, certain polyphenols showed cytotoxic effects on the body. A relevant example is gossypol, a polyphenol found in cottonseed oil known for its toxicity but also for its ability to induce infertility in men [146].

This double-edged blade has led researchers to study these compounds in more detail to conclude whether phenols could actually be used in vivo or whether all the qualities they provide are theoretical, and the results can only be obtained from in vitro studies. The reason why some researchers might consider the use of polyphenols only for in vitro experiments is the low concentration used, because a high concentration of polyphenols can lead to toxicity due to their hormetic nature. The hormetic phenomenon refers to the ability of certain compounds to behave as stimulants when administered in low doses and as toxic agents when administered in high doses [147]. On the other hand, a study reported by Martin [148] revealed that caffeic acid, a polyphenol frequently used in oil enrichment, can be a tumor suppressor at a $0.5-5 \mathrm{~g} \mathrm{~kg}^{-1}$ diet, a tumor promoter at a $5-10 \mathrm{~g} \mathrm{~kg}^{-1}$ diet, and a carcinogenic compound at a $>20 \mathrm{~g} \mathrm{~kg}^{-1}$ diet. The same study showed that ferulic acid, another main antioxidant used in the food industry, exerted both antitumoral activities on the tongue, skin, and colon and pro-tumoral activity on the liver when administered to rats at a $500 \mathrm{mg} \mathrm{kg}^{-1}$ diet [148]. Islam et al. [149] also pointed out that vanillic acid can induce acute toxicity in mice and rats at LD50 with a 2.691 and $5.020 \mathrm{mg} \mathrm{kg}^{-1}$ diet, syringic 
acid in rats at LD50 with a $>2000 \mathrm{mg} \mathrm{kg}^{-1}$ diet, and gallic acid in BEAS-2B (transformed or non-tumorigenic cells) at $25 \mu \mathrm{g} \mathrm{mL}^{-1}$ [149].

Even if all these results may seem alarming, it should be noted that these results are related to mice and rats. Cladis et al. [150] performed transformation of the data related to rats in order to find out the human polyphenol intake in a novel study. The team publicized that the no-observed-adverse-effect level (NOAEL) for blueberry polyphenols is $\geq 1000 \mathrm{mg} \mathrm{kg}^{-1} \mathrm{bw} / \mathrm{d}$ for OVX-SD rats, translating to a $70-\mathrm{kg}$ human consuming $\sim 10 \mathrm{~g}$ of blueberry polyphenols per day. The obtained amount is higher compared with the current available dietary supplements, so the researchers concluded that blueberry polyphenols are safe to consume [150]. However, more studies are needed to ascertain whether a particular extract of a specific by-product or food waste containing well-identified molecules exhibits or does not exhibit toxic effects toward human health and in which range of concentrations its use can be considered safe.

\section{Oil Blending as a Tool to Improve an Oil's Oxidative Stability}

The blending of two or more seed oils is an old approach employed to modify the fatty acid profile and to improve an oil's nutritional quality. The edible oil industry often uses the blending practice to produce blended oils with enhanced oxidative stability and improved functional characteristics [151]. This practice has gained renewed interest after the introduction in the market of new oils extracted from unconventional oil-bearing seeds. The blending with this kind of oils has economic and functional advantages, changing the physico-chemical and nutritional properties of the blends [151]. The main effect of blending is the modification of the fatty acid profile, particularly the ratio of saturated, mono-, and poly-unsaturated fatty acids and the ratio of essential fatty acids ( $\omega 3: \omega 6)$. Blending with an oil with a high unsaturation degree increases the nutritional properties and the health effects of the oils, but the drawback is that the use of a less stable oil may decrease the blend's oxidative stability during storage or cooking. Careful blending should be modulated based on the final use of the blended oil. In a diet rich in essential fatty acids, a healthy $\omega-3: \omega-6$ ratio, important in the prevention of many diseases, may be achieved by mixing oils to obtain a balanced fatty acid composition [152,153]. The mixture of sunflower oil with 20\% cold-pressed flaxseed oil produced an oil with an optimal $\omega-3: \omega-6$ ratio and with an enhanced level of bioactive compounds like tocopherols and carotenoids [152].

Table 2 reports some of the studies dealing with the effect of oil blending on the oils' oxidative stability. The blending of linseed oil with corn, sesame, and bitter almond oils at different ratios enhanced the linseed oxidative stability as determined by the Rancimat method at 353, 373, and $393 \mathrm{~K}$ [154]. The blending of Moringa oleifera oil with sunflower and soybean oil, by changing the proportion of MUFAs and PUFAs, determined an enhancement in the oxidative stability of the oils during storage at room temperature for 180 days and increased the oils' stability during heat treatment at $180^{\circ} \mathrm{C}$ for $42 \mathrm{~h}$, with a 6-h heating cycle per day [155]. Chia oil is rich in $\omega-3$ fatty acids that own beneficial properties for human health but are highly susceptible to oxidative damage. The blends of chia oil with walnut, almond, or sesame oils increased the oxidative stability of the oils subjected to accelerated storage conditions while keeping a high level of $\omega-3$ fatty acids [156]. The blending of sunflower oil with pomegranate seed oil (85:15) determined an increase in the oxidative stability during an accelerated storage test at $60^{\circ} \mathrm{C}$ for 20 days with respect to sunflower oil alone [157]. The addition of $15 \%$ pomegranate seed oil to the sunflower oil changed the fatty acid profile by increasing the concentrations of the primary saturated fatty acids like palmitic and stearic acids and enhanced the levels of the phenolic compounds, carotenoids, and $\alpha$-tocopherol. 
Table 2. Oil blends used to enhance the oxidative stability of edible oils.

\begin{tabular}{|c|c|c|c|c|}
\hline $\begin{array}{c}\text { Oil Blend } \\
\text { (First }+ \text { Second Component) }\end{array}$ & $\begin{array}{l}\text { Concentration of the } \\
\text { Second Blend } \\
\text { Component }\end{array}$ & Analytical Approach & Main Results & References \\
\hline Sunflower oil + Sclerocarya oil & $10,20,30$, and $40 \%$ & $\begin{array}{l}\text { Oxidative stability (Rancimat } 120 \mathrm{C} \text { ) and } \\
\text { stability at } 70 \mathrm{C} \text { using peroxide value. }\end{array}$ & $\begin{array}{l}\text { The oxidative stability in the Rancimat test was improved from } \\
47 \text { to } 147 \% \text { in oil blends compared with sunflower oil alone. } \\
\text { Storage of the blends at } 70^{\circ} \mathrm{C} \text { showed that peroxide value of the } \\
\text { blends was remarkably lower than sunflower alone. }\end{array}$ & [158] \\
\hline $\begin{array}{l}\text { Sunflower oil (SFO) + Moringa } \\
\text { oleifera oil (MOO)Soybean oil } \\
(\mathrm{SBO})+\mathrm{MOO}\end{array}$ & $20,40,60$, and $80 \%$ & $\begin{array}{l}\text { Storage test: oils stored at room } \\
\text { temperature for } 180 \text { days. Peroxide value } \\
\text { (PV), iodine value (IV), and induction } \\
\text { period (IP, Rancimat test) were evaluated } \\
\text { monthly. } \\
\text { Thermal stability test: heating at } 180^{\circ} \mathrm{C} \text { for } \\
42 \mathrm{~h} \text { (6-h heating cycles each day). }\end{array}$ & $\begin{array}{l}\text { The storage test showed an improvement of the oxidative } \\
\text { stability of blends with increasing MOO concentration. Each } \\
20 \% \text { addition of MOO resulted in decreases of PV and an } \\
\text { increases of IP. The heating performance test revealed the } \\
\text { SBO:MOO }(20: 80 w / w) \text { blend was the most stable. }\end{array}$ & [155] \\
\hline $\begin{array}{l}\text { Coconut oil + palm oil } \\
\text { Coconut oil + sunflower oil } \\
\text { Coconut oil + soybean oil }\end{array}$ & 20,50 , and $80 \%$ & $\begin{array}{l}\text { Storage test: } 6 \text { weeks at } 37^{\circ} \mathrm{C} \text {. Peroxide } \\
\text { value (PV), fatty acid composition, and } \\
\text { antioxidant activity. }\end{array}$ & $\begin{array}{l}\text { Blending coconut oil with other vegetable oils increased the } \\
\text { medium chain fatty acid concentration and the oxidative } \\
\text { stability to the blends. }\end{array}$ & [159] \\
\hline $\begin{array}{l}\text { Rapeseed oil + rice bran oil } \\
\text { Rapeseed oil + black cumin oil }\end{array}$ & 5,10 , and $20 \%$ & $\begin{array}{l}\text { Oxidative stability index (Rancimat test), } \\
\text { phytosterols, fatty acids, and } \\
\text { tochochromanols. }\end{array}$ & $\begin{array}{l}\text { The blends with black cumin seed oil had higher level of } \alpha \text { - and } \\
\gamma \text {-tocopherols and all isomers of tocotrienols. } \\
\text { Blends with rice bran oil had high tocotrienol, } \beta \text {-sitosterol, and } \\
\text { squalene levels. Blending resulted in lowering ratio of } \\
\text { PUFA:SFA and improved the stability of these oils. }\end{array}$ & [160] \\
\hline $\begin{array}{l}\text { Sunflower oil (SFO) }+ \\
\text { cold-pressed black cumin } \\
\text { oil (BCO) }\end{array}$ & 5,10, and $20 \%$ & $\begin{array}{l}\text { Thermally accelerated oxidation conditions } \\
\text { with Rancimat method (110C) and Schaal } \\
\text { oven test }(60 \mathrm{C}) \text {. Peroxide value (PV), } \\
\text { conjugated dienes (CD), and conjugated } \\
\text { trienes (CT). Volatile oxidation compounds. }\end{array}$ & $\begin{array}{l}\text { BCO increased the stability of SFO at high temperatures } \\
\text { according to induction period times. SFO:BCO (80:20) blends } \\
\text { had lower PV at the end of storage at } 60^{\circ} \mathrm{C} \text { (Schaal oven test). } \\
\text { Stability of blends was better than SO, most likely due to } \\
\text { changes in the levels of thymoquinone and tocopherols found } \\
\text { in BCO. }\end{array}$ & [161] \\
\hline $\begin{array}{l}\text { Butter oil + crude mango kernel } \\
\text { oil }(\mathrm{MKO})\end{array}$ & $2.5,5,7.5$, and $10 \%$ & $\begin{array}{l}\text { Storage at } 25^{\circ} \mathrm{C} \text { and } 55^{\circ} \mathrm{C} \text { for } 6 \text { months. } \\
\text { Induction period (rancimat methd) } \\
\text { peroxide values, anisidine values, and } \\
\text { iodine values were measured at } 0,45 \text {, and } \\
90 \text { days. }\end{array}$ & $\begin{array}{l}\text { Supplementation of MKO oil in butter oil inhibited oil oxidation } \\
\text { at ambient and accelerated oxidation, as showed by the low PV } \\
\text { and anisidine values of blends after } 90 \text { days of storage. } \\
\text { Induction period of all the treatments increased as a function of } \\
\text { the addition of MKO. }\end{array}$ & [162] \\
\hline
\end{tabular}


Table 2. Cont.

\begin{tabular}{|c|c|c|c|c|}
\hline $\begin{array}{c}\text { Oil Blend } \\
\text { (First }+ \text { Second Component) }\end{array}$ & $\begin{array}{l}\text { Concentration of the } \\
\text { Second Blend } \\
\text { Component }\end{array}$ & Analytical Approach & Main Results & References \\
\hline $\begin{array}{l}\text { Chia seed (Salvia hispanica L.) oil } \\
\text { (CO) + walnut (WO), almond } \\
\text { (AO), virgin and roasted sesame } \\
\text { oils (VSO, RSO) }\end{array}$ & 60,70 , and $80 \%$ & $\begin{array}{l}\text { Accelerated storage test (Schaal oven test } \\
(\mathrm{SOT}) 40 \pm 1^{\circ} \mathrm{C}, 12 \text { days). Peroxide value } \\
(\mathrm{PV}) \text {, conjugated dienes (CD), conjugated } \\
\text { trienes (CT), p-anisidine value (PAV), free } \\
\text { fatty acid content, antioxidant compounds, } \\
\text { and induction time (Rancimat method). }\end{array}$ & $\begin{array}{l}\text { The blends presented a higher induction period than chia oil } \\
\text { alone. Sesame oil blends (VSO and RSO) were the most stable, } \\
\text { folowed by CO:AO blends. }\end{array}$ & [156] \\
\hline $\begin{array}{l}\text { Linseed oil + corn, canola, sesame, } \\
\text { and bitter almond oils }\end{array}$ & $33,66 \%$ & $\begin{array}{l}\text { Oxidative stability index (OSI) as } \\
\text { determined by the Rancimat method at 353, } \\
\text { 373, and } 393 \mathrm{~K} \text {. }\end{array}$ & $\begin{array}{l}\text { Blending linseed oil with } 66 \% \text { corn, bitter almond, sesame, and } \\
\text { canola oil increased the OSI value of linseed oil by } 67.05 \% \text {, } \\
61.68 \%, 60.12 \% \text {, and } 59.13 \% \text {. }\end{array}$ & [154] \\
\hline Chia oil + sesame oil & $84.5,89.6,92.3$, and $93.9 \%$ & $\begin{array}{l}\text { Oxidative stability index (OSI), with the } \\
\text { Rancimat method, and shelf life (oxidative } \\
\text { stability index at } 25^{\circ} \mathrm{C}, \mathrm{OSI}_{25} \text { ). } \\
\text { Acidity, peroxide value (PV), p-anisidine } \\
\text { value (p-AV), and the total oxidation } \\
\text { value (TotOx). }\end{array}$ & $\begin{array}{l}\text { The supplementation of chia oil with sesame oil increased the OSI } \\
\text { value and the shelf life (oxidative stability index at } 25^{\circ} \mathrm{C}, \mathrm{OSI}_{25} \text { ). }\end{array}$ & [164] \\
\hline $\begin{array}{l}\text { Soybean oil (SBO) + sesame seed } \\
\text { oil (SSO) }\end{array}$ & 40,50 , and $60 \%$ & $\begin{array}{l}3 \text { frying cycles. } \\
\text { At the end of each cycle, the free fatty acid } \\
\text { (FFA), peroxide value, and acid value were } \\
\text { determined. Characterization of fresh and } \\
\text { fried oil blends by Fourier transform } \\
\text { infrared spectroscopy (FTIR). }\end{array}$ & $\begin{array}{l}\text { The blend with the ratio of } 60 \% \text { had the lowest peroxide value. } \\
\text { The blending of SBO with SSO improved the thermal stability, } \\
\text { as sesame seed oil contains high levels of antioxidants such as } \\
\text { sesamin, sesamol, and tocopherol. }\end{array}$ & [165] \\
\hline
\end{tabular}


Table 2. Cont.

\begin{tabular}{|c|c|c|c|c|}
\hline $\begin{array}{c}\text { Oil Blend } \\
\text { (First }+ \text { Second Component) }\end{array}$ & $\begin{array}{l}\text { Concentration of the } \\
\text { Second Blend } \\
\text { Component }\end{array}$ & Analytical Approach & Main Results & References \\
\hline $\begin{array}{l}\text { Virgin olive oil (VOO) + sesame } \\
\text { (SSO), flaxseed (VFO), hazelnut } \\
\text { (VHO), and pistachio (VPO) oils }\end{array}$ & $\begin{array}{l}\text { SSO } 5,15 \% \\
\text { VFO } 3,10 \% \\
\text { VPO or VHO } 50,75 \%\end{array}$ & $\begin{array}{l}\text { Oxidative stability by Rancimat method. } \\
\text { Shelf life testing at room temperature for } \\
24 \text { days }\left(25^{\circ} \mathrm{C}\right) \text { and under accelerated } \\
\text { shelf-life conditions }\left(55^{\circ} \mathrm{C}\right) \text { (ASLT). }\end{array}$ & $\begin{array}{l}\text { The oxidative stability test showed that the oil blends } \\
\text { maintained similar stabilities of VOO under normal and } \\
\text { accelerated storage conditions. }\end{array}$ & [166] \\
\hline $\begin{array}{l}\text { Sunflower oil }(\mathrm{SFO})+ \\
\text { pomegranate seed oil }(\mathrm{PSO})\end{array}$ & $10,15,20 \%(w / w)$ & $\begin{array}{l}\text { Accelerated storage test was conducted } \\
\text { using the best blending ratio }(85: 15) \text { at } \\
60 \pm 2{ }^{\circ} \mathrm{C} \text { for } 20 \text { days following the } \\
\text { evolution of the peroxide value, } \rho \text {-anisidine } \\
\text { value, and total oxidation value. }\end{array}$ & $\begin{array}{l}\text { Blending of SO with PSO improved total phenols, total } \\
\text { carotenoids, and tocopherol content. Blended oils exhibited } \\
\text { better oxidative stability than SO, as shown by the low peroxide } \\
\text { and } \rho \text {-anisidine values. Blending SO with PSO decreased the } \\
\text { rate of hydroperoxides formation during the accelerated } \\
\text { storage period. }\end{array}$ & [157] \\
\hline
\end{tabular}


The resistance to oxidation of the oil blends is strongly affected by the chemical features and the relative percentage of the starting oils in the blends. An oil with a high unsaturation degree is more susceptible to oxidation, and thus its percentage in the blend should be tailored while considering its fatty acid composition and the presence of natural antioxidants.

\section{Conclusions}

The stabilization of edible oils and their protection from oxidation would be favorable for oil producers and food processing industries, allowing a better exploitation of the resources and supplying safer products to consumers. Natural antioxidants have been suggested as alternatives to synthetic additives for the protection of edible oils against oxidative damage. The use of natural antioxidants recovered with sustainable methodologies from food wastes or by-products originating from food processing industries is an emerging approach in the perspective of a circular economy and to meet consumers demand for natural and safer foods. The reuse and exploitation of new unconventional and alternative sources, such as the wastes of food processing industries, represent key issues in this direction, following the green transition and the principles of a circular economy.

The literature survey conducted in this review highlighted a huge amount of papers explaining the role of antioxidants in the protection of edible oils against autoxidation during storage or thermal treatments due to cooking. However, the sustainability of the biomolecule extraction processes and the design of proper oil enrichments in terms of quality and the amount of extracts to be added are moving through their first steps, and further studies are needed.

Furthermore, the enrichment methods should be further developed both to protect the extracts from thermal damage during high-temperature treatments occurring in frying and cooking conditions and to provide a controlled release of the active ingredients. The development of nanotechnologies for the encapsulation of non-lipophilic antioxidants are a step in this direction. This review has also considered the safety concerns for human health associated with the use of natural antioxidants, pointing out a double effect of polyphenols. This highlights the need for a multidisciplinary and integrated approach in the studies of stabilization of edible oils with natural antioxidants.

Author Contributions: Conceptualization, A.D. and A.F.; writing-original draft preparation, D.S., E.H.S., S.G., M.M., S.M., N.S.Y., A.C.K., C.K.G., M.L., G.L.-B., Z.D., A.D. and A.F.; writing-review and editing, A.F., A.D. and D.S. All authors have read and agreed to the published version of the manuscript.

Funding: This work was partially funded by the project SYSTEMIC “An integrated approach to the challenge of sustainable food systems adaptive and mitigatory strategies to address climate change and malnutrition", Knowledge hub on Nutrition and Food Security, in a joint action of JPI HDHL, JPI OCEANS and FACCE JPI launched in 2019 under the ERA NET ERA HDHL (n 696295).

Informed Consent Statement: Not applicable.

Data Availability Statement: Not applicable.

Conflicts of Interest: The authors declare no conflict of interest.

\section{References}

1. Guillén, M.D.; Cabo, N.; Ibargoitia, M.L.; Ruiz, A. Study of both Sunflower Oil and Its Headspace throughout the Oxidation Process. Occurrence in the Headspace of Toxic Oxygenated Aldehydes. J. Agric. Food Chem. 2005, 53, 1093-1101. [CrossRef] [PubMed]

2. Viana da Silva, M.; Santos, M.R.C.; Alves Silva, I.R.; Macedo Viana, E.B.; Dos Anjos, D.A.; Santos, I.A.; Barbosa de Lima, N.G.; Wobeto, C.; Jorge, N.; Lannes, S.C.D.S. Synthetic and Natural Antioxidants Used in the Oxidative Stability of Edible Oils: An Overview. Food Rev. Int. 2021, 1-24. [CrossRef]

3. Metzner Ungureanu, C.-R.; Poiana, M.-A.; Cocan, I.; Lupitu, A.I.; Alexa, E.; Moigradean, D. Strategies to Improve the ThermoOxidative Stability of Sunflower Oil by Exploiting the Antioxidant Potential of Blueberries Processing Byproducts. Molecules 2020, 25, 5688. [CrossRef] [PubMed] 
4. $\quad$ Odeh, D.; Kraljić, K.; Benussi Skukan, A.; Škevin, D. Oxidative Stability, Microbial Safety, and Sensory Properties of Flaxseed (Linum usitatissimum L.) Oil Infused with Spices and Herbs. Antioxidants 2021, 10, 785. [CrossRef]

5. Taghvaei, M.; Jafari, S.M. Application and stability of natural antioxidants in edible oils in order to substitute synthetic additives. J. Food Sci. Technol. 2015, 52, 1272-1282. [CrossRef] [PubMed]

6. Xu, X.; Liu, A.; Hu, S.; Ares, I.; Martínez-Larrañaga, M.-R.; Wang, X.; Martínez, M.; Anadón, A.; Martínez, M.-A. Synthetic phenolic antioxidants: Metabolism, hazards and mechanism of action. Food Chem. 2021, 353, 129488. [CrossRef]

7. Blasi, F; Cossignani, L. An Overview of Natural Extracts with Antioxidant Activity for the Improvement of the Oxidative Stability and Shelf Life of Edible Oils. Processes 2020, 8, 956. [CrossRef]

8. Bodoira, R.M.; Penci, M.C.; Ribotta, P.D.; Martínez, M.L. Chia (Salvia hispanica L.) oil stability: Study of the effect of natural antioxidants. LWT 2017, 75, 107-113. [CrossRef]

9. Carelli, A.A.; Franco, I.C.; Crapiste, G.H. Effectiveness of added natural antioxidants in sunflower oil. Grasas Aceites 2005, 56, 303-310. [CrossRef]

10. Drinić, Z.; Mudrić, J.; Zdunić, G.; Bigović, D.; Menković, N.; Šavikin, K. Effect of pomegranate peel extract on the oxidative stability of pomegranate seed oil. Food Chem. 2020, 333, 127501. [CrossRef] [PubMed]

11. Drozłowska, E.; Bartkowiak, A.; Trocer, P.; Kostek, M.; Tarnowiecka-Kuca, A.; Bienkiewicz, G.; Łopusiewicz, Ł. The Influence of Flaxseed Oil Cake Extract on Oxidative Stability of Microencapsulated Flaxseed Oil in Spray-Dried Powders. Antioxidants 2021, 10, 211. [CrossRef]

12. Ghorbani Gorji, S.; Smyth, H.E.; Sharma, M.; Fitzgerald, M. Lipid oxidation in mayonnaise and the role of natural antioxidants: A review. Trends Food Sci. Technol. 2016, 56, 88-102. [CrossRef]

13. Grosshagauer, S.; Steinschaden, R.; Pignitter, M. Strategies to increase the oxidative stability of cold pressed oils. LWT 2019, 106, 72-77. [CrossRef]

14. Iqbal, S.; Haleem, S.; Akhtar, M.; Zia-ul-Haq, M.; Akbar, J. Efficiency of pomegranate peel extracts in stabilization of sunflower oil under accelerated conditions. Food Res. Int. 2008, 41, 194-200. [CrossRef]

15. Next Generation EU. Available online: https:/ / europa.eu/next-generation-eu/index_en (accessed on 16 December 2021).

16. Rao, M.; Bast, A.; de Boer, A. Valorized Food Processing By-Products in the EU: Finding the Balance between Safety, Nutrition, and Sustainability. Sustainability 2021, 13, 4428. [CrossRef]

17. Choe, E.; Min, D.B. Mechanisms and Factors for Edible Oil Oxidation. Compr. Rev. Food Sci. Food Saf. 2006, 5, 169-186. [CrossRef]

18. Hu, M.; McClements, D.J.; Decker, E.A. Lipid Oxidation in Corn Oil-in-Water Emulsions Stabilized by Casein, Whey Protein Isolate, and Soy Protein Isolate. J. Agric. Food Chem. 2003, 51, 1696-1700. [CrossRef]

19. Faraji, H.; McClements, D.J.; Decker, E.A. Role of Continuous Phase Protein on the Oxidative Stability of Fish Oil-in-Water Emulsions. J. Agric. Food Chem. 2004, 52, 4558-4564. [CrossRef]

20. Elias, R.J.; McClements, D.J.; Decker, E.A. Antioxidant Activity of Cysteine, Tryptophan, and Methionine Residues in Continuous Phase $\beta$-Lactoglobulin in Oil-in-Water Emulsions. J. Agric. Food Chem. 2005, 53, 10248-10253. [CrossRef]

21. Inchingolo, R.; Bayram, I.; Uluata, S.; Kiralan, S.S.; Rodriguez-Estrada, M.T.; McClements, D.J.; Decker, E.A. Ability of Sodium Dodecyl Sulfate (SDS) Micelles to Increase the Antioxidant Activity of $\alpha$-Tocopherol. J. Agric. Food Chem. 2021, 69, 5702-5708. [CrossRef]

22. van Eck, N.J.; Waltman, L. Software survey: VOSviewer, a computer program for bibliometric mapping. Scientometrics 2010, 84, 523-538. [CrossRef] [PubMed]

23. Waltman, L.; van Eck, N.J.; Noyons, E.C.M. A unified approach to mapping and clustering of bibliometric networks. J. Informetr. 2010, 4, 629-635. [CrossRef]

24. Van Eck, N.J.; Waltman, L. Text Mining and Visualization Using VOS Viewer. Available online: http://arxiv.org/ftp/arxiv/ papers/1109/1109.2058.pdf (accessed on 24 October 2021).

25. Ramadan, M.F.; Kroh, L.W.; Mörsel, J.-T. Radical Scavenging Activity of Black Cumin (Nigella sativa L.), Coriander (Coriandrum sativum L.), and Niger (Guizotia abyssinica Cass.) Crude Seed Oils and Oil Fractions. J. Agric. Food Chem. 2003, 51, 6961-6969. [CrossRef] [PubMed]

26. Fernández-Bolaños, J.; Rodríguez, G.; Rodríguez, R.; Heredia, A.; Guillén, R.; Jiménez, A. Production in Large Quantities of Highly Purified Hydroxytyrosol from Liquid-Solid Waste of Two-Phase Olive Oil Processing or "Alperujo". J. Agric. Food Chem. 2002, 50, 6804-6811. [CrossRef] [PubMed]

27. Difonzo, G.; Troilo, M.; Squeo, G.; Pasqualone, A.; Caponio, F. Functional compounds from olive pomace to obtain high-added value foods-A review. J. Sci. Food Agric. 2021, 101, 15-26. [CrossRef] [PubMed]

28. Angelovič, M.; Jablonický, J.; Tkáč, Z.; Angelovič, M. Oxidative stability of fatty acid alkyl esters: A review. Potravin. Slovak J. Food Sci. 2015, 9, 417-426. [CrossRef]

29. Cisneros-Yupanqui, M.; Chalova, V.I.; Kalaydzhiev, H.R.; Mihaylova, D.; Krastanov, A.I.; Lante, A. Preliminary Characterisation of Wastes Generated from the Rapeseed and Sunflower Protein Isolation Process and Their Valorisation in Delaying Oil Oxidation. Food Bioprocess Technol. 2021, 14, 1962-1971. [CrossRef]

30. Luzi, F.; Pannucci, E.; Clemente, M.; Grande, E.; Urciuoli, S.; Romani, A.; Torre, L.; Puglia, D.; Bernini, R.; Santi, L. Hydroxytyrosol and Oleuropein-Enriched Extracts Obtained from Olive Oil Wastes and By-Products as Active Antioxidant Ingredients for Poly (Vinyl Alcohol)-Based Films. Molecules 2021, 26, 2104. [CrossRef] [PubMed] 
31. Jolayemi, O.S.; Stranges, N.; Flamminii, F.; Casiraghi, E.; Alamprese, C. Influence of Free and Encapsulated Olive Leaf Phenolic Extract on the Storage Stability of Single and Double Emulsion Salad Dressings. Food Bioprocess Technol. 2021, 14, 93-105. [CrossRef]

32. Branciari, R.; Galarini, R.; Giusepponi, D.; Trabalza-Marinucci, M.; Forte, C.; Roila, R.; Miraglia, D.; Servili, M.; Acuti, G.; Valiani, A. Oxidative Status and Presence of Bioactive Compounds in Meat from Chickens Fed Polyphenols Extracted from Olive Oil Industry Waste. Sustainability 2017, 9, 1566. [CrossRef]

33. Oils and Fats in the Market Place. Available online: https://lipidlibrary.aocs.org/resource-material/market-trends/oils-andfats-in-the-market-place (accessed on 2 November 2021).

34. Woodgate, S.L.; van der Veen, J.T. Fats and Oils-Animal Based. In Food Processing; John Wiley \& Sons, Ltd.: Oxford, UK, 2014; pp. 481-499.

35. The Four Major Vegetable Oils. Available online: https://lipidlibrary.aocs.org/resource-material/market-trends/individualcommodity-oils-and-fats (accessed on 2 November 2021).

36. Kim, J.; Kim, D.N.; Lee, S.H.; Yoo, S.-H.; Lee, S. Correlation of fatty acid composition of vegetable oils with rheological behaviour and oil uptake. Food Chem. 2010, 118, 398-402. [CrossRef]

37. Akoh, C.C. (Ed.) Food Lipids. Chemistry, Nutrition, and Biotechnology, 4th ed.; CRC Press: Boca Raton, FL, USA, 2017.

38. Li, R.; Xia, Q.; Tang, M.; Zhao, S.; Chen, W.; Lei, X.; Bai, X. Chemical composition of Chinese palm fruit and chemical properties of the oil extracts. Afr. J. Biotechnol. 2012, 11, 9377-9382. [CrossRef]

39. Rasor, A.S.; Duncan, S.E. Fats and Oils-Plant Based. In Food Processing; John Wiley \& Sons, Ltd.: Oxford, UK, 2014; pp. 457-480.

40. Boskou, D. (Ed.) Olive Oil. Minor Constituents and Health, 1st ed.; CRC Press: Boca Raton, FL, USA, 2008.

41. Fung, T.T.; Isanaka, S.; Hu, F.B.; Willett, W.C. International food group-based diet quality and risk of coronary heart disease in men and women. Am. J. Clin. Nutr. 2018, 107, 120-129. [CrossRef]

42. Jimenez-Torres, J.; Alcalá-Diaz, J.F.; Torres-Peña, J.D.; Gutierrez-Mariscal, F.M.; Leon-Acuña, A.; Gómez-Luna, P.; FernándezGandara, C.; Quintana-Navarro, G.M.; Fernandez-Garcia, J.C.; Perez-Martinez, P.; et al. Mediterranean Diet Reduces Atherosclerosis Progression in Coronary Heart Disease: An Analysis of the CORDIOPREV Randomized Controlled Trial. Stroke 2021, 52, 3440-3449. [CrossRef] [PubMed]

43. Zamuz, S.; Purriños, L.; Tomasevic, I.; Domínguez, R.; Brnčić, M.; Barba, F.J.; Lorenzo, J.M. Consumer Acceptance and Quality Parameters of the Commercial Olive Oils Manufactured with Cultivars Grown in Galicia (NW Spain). Foods 2020, 9, 427. [CrossRef]

44. Matthäus, B.; Guillaume, D.; Gharby, S.; Haddad, A.; Harhar, H.; Charrouf, Z. Effect of processing on the quality of edible argan oil. Food Chem. 2010, 120, 426-432. [CrossRef]

45. Matthäus, B.; Brühl, L. Quality parameters for the evaluation of cold-pressed edible argan oil. J. Verbrauch. Lebensm. 2015, 10, 143-154. [CrossRef]

46. Maszewska, M.; Florowska, A.; Dłużewska, E.; Wroniak, M.; Marciniak-Lukasiak, K.; Żbikowska, A. Oxidative Stability of Selected Edible Oils. Molecules 2018, 23, 1746. [CrossRef]

47. Guillén, M.D.; Ruiz, A. Monitoring the oxidation of unsaturated oils and formation of oxygenated aldehydes by proton NMR Eur. J. Lipid Sci. Technol. 2005, 107, 36-47. [CrossRef]

48. Gharby, S.; Harhar, H.; Guillaume, D.; Haddad, A.; Matthäus, B.; Charrouf, Z. Oxidative stability of edible argan oil: A two-year study. LWT-Food Sci. Technol. 2011, 44, 1-8. [CrossRef]

49. Laguerre, M.; Bily, A.; Roller, M.; Birtić, S. Mass Transport Phenomena in Lipid Oxidation and Antioxidation. Annu. Rev. Food Sci. Technol. 2017, 8, 391-411. [CrossRef]

50. Ghnimi, S.; Budilarto, E.; Kamal-Eldin, A. The New Paradigm for Lipid Oxidation and Insights to Microencapsulation of Omega-3 Fatty Acids. Compr. Rev. Food Sci. Food Saf. 2017, 16, 1206-1218. [CrossRef] [PubMed]

51. Kasaikina, V.D.K.O.T. Lipid Oxidation in Homogeneous and Micro-Heterogeneous Media in Presence of Prooxidants, Antioxidants and Surfactants. In Lipid Peroxidation; Catala, A., Ed.; IntechOpen: London, UK, 2012.

52. Haman, N.; Bodner, M.; Ferrentino, G.; Scampicchio, M. Lipid autoxidation of fish, lard, corn and linseed oils by isothermal calorimetry. Ital. J. Food Sci. 2018, 31, 323. [CrossRef]

53. Na, L.; Lu, H.; Xin, G.; Zhiping, T.; Jun, L. DFT Study of Oxidation Reaction Paths for Ethanol Gasoline. J. Energy Nat. Resour. 2020, 9, 39-43. [CrossRef]

54. Gharby, S.; Guillaume, D.; Elibrahimi, M.; Charrouf, Z. Physico-Chemical Properties and Sensory Analysis of Deodorized Argan Oil. ACS Food Sci. Technol. 2021, 1, 275-281. [CrossRef]

55. Gharby, S.; Guillaume, D.; Nounah, I.; Harhar, H.; Hajib, A.; Matthäus, B.; Charrouf, Z. Shelf-life of Moroccan prickly pear (Opuntia ficus-indica) and argan (Argania spinosa) oils: A comparative study. Grasas Aceites 2021, 72, e397. [CrossRef]

56. Gharby, S.; Hajib, A.; Ibourki, M.; Sakar, E.H.; Nounah, I.; Moudden, H.E.L.; Elibrahimi, M.; Harhar, H. Induced changes in olive oil subjected to various chemical refining steps: A comparative study of quality indices, fatty acids, bioactive minor components, and oxidation stability kinetic parameters. Chem. Data Collect. 2021, 33, 100702. [CrossRef]

57. van der Merwe, G.H.; du Plessis, L.M.; Taylor, J.R. Changes in chemical quality indices during long-term storage of palm-olein oil under heated storage and transport-type conditions. J. Sci. Food Agric. 2004, 84, 52-58. [CrossRef]

58. Cong, S.; Dong, W.; Zhao, J.; Hu, R.; Long, Y.; Chi, X. Characterization of the Lipid Oxidation Process of Robusta Green Coffee Beans and Shelf Life Prediction during Accelerated Storage. Molecules 2020, 25, 1157. [CrossRef] 
59. Tavakoli, H.R.; Naderi, M.; Jafari, S.M.; Naeli, M.H. Postmarketing surveillance of the oxidative stability for cooking oils, frying oils, and vanaspati supplied in the retail market. Food Sci. Nutr. 2019, 7, 1455-1465. [CrossRef] [PubMed]

60. Gharby, S.; Harhar, H.; Mamouni, R.; Matthäus, B.; Ait Addi, E.H.; Charrouf, Z. Chemical Characterization and Kinetic parameter determination under Rancimat test conditions of four monovarietal virgin olive oils grown in Morocco. OCL 2016, 23, A401. [CrossRef]

61. Figueredo, I.d.M.; Rios, M.A.d.S.; Cavalcante, C.L.; Luna, F.M.T. Effects of Amine and Phenolic Based Antioxidants on the Stability of Babassu Biodiesel Using Rancimat and Differential Scanning Calorimetry Techniques. Ind. Eng. Chem. Res. 2020, 59, 18-24. [CrossRef]

62. Symoniuk, E.; Ratusz, K.; Krygier, K. Comparison of the oxidative stability of linseed (Linum usitatissimum L.) oil by pressure differential scanning calorimetry and Rancimat measurements. J. Food Sci. Technol. 2016, 53, 3986-3995. [CrossRef] [PubMed]

63. Le Priol, L. Study of the co-encapsulation of edible oxidable oils and phenolic antioxidants. In Étude de la co-Encapsulation d'huiles Alimentaires Oxydables et d'antioxydants Phénoliques; Université de Technologie de Compiègne: Compiègne, France, 2019.

64. Houmy, N.; Mansouri, F.; Benmoumen, A.; Elmouden, S.; Boujnah, M.; Sindic, M.; Fauconnier, M.-L.; Serghini-Caid, H.; Elamrani, A. Characterization of almond kernel oils of five almonds varieties cultivated in Eastern Morocco. Cah. Options Méditerranéennes 2016, 119, 317-321.

65. Cui, L.; Lahti, P.M.; Decker, E.A. Evaluating Electron Paramagnetic Resonance (EPR) to Measure Lipid Oxidation Lag Phase for Shelf-Life Determination of Oils. J. Am. Oil Chem. Soc. 2017, 94, 89-97. [CrossRef]

66. Merkx, D.W.H.; Plankensteiner, L.; Yu, Y.; Wierenga, P.A.; Hennebelle, M.; Van Duynhoven, J.P.M. Evaluation of PBN spin-trapped radicals as early markers of lipid oxidation in mayonnaise. Food Chem. 2021, 334, 127578. [CrossRef] [PubMed]

67. Ricca, M.; Fodera, V.; Vetri, V.; Buscarino, G.; Montalbano, M.; Leone, M. Oxidation Processes in Sicilian Olive Oils Investigated by a Combination of Optical and EPR Spectroscopy. J. Food Sci. 2012, 77, C1084-C1089. [CrossRef]

68. Ottaviani, M.F.; Spallaci, M.; Cangiotti, M.; Bacchiocca, M.; Ninfali, P. Electron paramagnetic resonance investigations of free radicals in extra virgin olive oils. J. Agric. Food Chem. 2001, 49, 3691-3696. [CrossRef] [PubMed]

69. Papadimitriou, V.; Maridakis, G.A.; Sotiroudis, T.G.; Xenakis, A. Antioxidant activity of polar extracts from olive oil and olive mill wastewaters: An EPR and photometric study. Eur. J. Lipid Sci. Technol. 2005, 107, 513-520. [CrossRef]

70. Jiang, S.; Xie, Y.; Li, M.; Guo, Y.; Cheng, Y.; Qian, H.; Yao, W. Evaluation on the oxidative stability of edible oil by electron spin resonance spectroscopy. Food Chem. 2020, 309, 125714. [CrossRef] [PubMed]

71. Velasco, J.; Andersen, M.L.; Skibsted, L.H. ESR spin trapping for in situ detection of radicals involved in the early stages of lipid oxidation of dried microencapsulated oils. Food Chem. 2021, 341, 128227. [CrossRef] [PubMed]

72. Fadda, A.; Molinu, M.G.; Deiana, P.; Sanna, D. Electron Paramagnetic Resonance Spin Trapping of Sunflower and Olive Oils Subjected to Thermal Treatment: Optimization of Experimental and Fitting Parameters. ACS Food Sci. Technol. 2021, 1, 1294-1303. [CrossRef]

73. Shahidi, F.; Zhong, Y. Lipid oxidation and improving the oxidative stability. Chem. Soc. Rev. 2010, 39, 4067-4079. [CrossRef] [PubMed]

74. Yang, Y.; Song, X.; Sui, X.; Qi, B.; Wang, Z.; Li, Y.; Jiang, L. Rosemary extract can be used as a synthetic antioxidant to improve vegetable oil oxidative stability. Ind. Crops Prod. 2016, 80, 141-147. [CrossRef]

75. Jiménez, P.; García, P.; Bustamante, A.; Barriga, A.; Robert, P. Thermal stability of oils added with avocado (Persea americana cv. Hass) or olive (Olea europaea cv. Arbequina) leaf extracts during the French potatoes frying. Food Chem. 2017, 221, 123-129. [CrossRef] [PubMed]

76. Te Morenga, L.; Montez, J.M. Health effects of saturated and trans-fatty acid intake in children and adolescents: Systematic review and meta-analysis. PLoS ONE 2017, 12, e0186672. [CrossRef]

77. Chong, Y.M.; Chang, S.K.; Sia, W.C.M.; Yim, H.S. Antioxidant efficacy of mangosteen (Garcinia mangostana Linn.) peel extracts in sunflower oil during accelerated storage. Food Biosci. 2015, 12, 18-25. [CrossRef]

78. Dairi, S.; Galeano-Díaz, T.; Acedo-Valenzuela, M.I.; Godoy-Caballero, M.P.; Dahmoune, F.; Remini, H.; Madani, K. Monitoring oxidative stability and phenolic compounds composition of myrtle-enriched extra virgin olive during heating treatment by flame, oven and microwave using reversed phase dispersive liquid-liquid microextraction (RP-DLLME)-HPLC-DAD-FLD method. Ind. Crops Prod. 2015, 65, 303-314. [CrossRef]

79. Valko, M.; Rhodes, C.J.; Moncol, J.; Izakovic, M.; Mazur, M. Free radicals, metals and antioxidants in oxidative stress-induced cancer. Chem.-Biol. Interact. 2006, 160, 1-40. [CrossRef] [PubMed]

80. Greenwood, N.N.; Earnshaw, A. (Eds.) Iron, Ruthenium and Osmium. In Chemistry of the Elements, 2nd ed.; ButterworthHeinemann: Oxford, UK, 1997; Chapter 25; pp. 1070-1112.

81. Perron, N.R.; Wang, H.C.; DeGuire, S.N.; Jenkins, M.; Lawson, M.; Brumaghim, J.L. Kinetics of iron oxidation upon polyphenol binding. Dalton Trans. 2010, 39, 9982-9987. [CrossRef] [PubMed]

82. Blekas, G.; Tsimidou, M.; Boskou, D. Contribution of $\alpha$-tocopherol to olive oil stability. Food Chem. 1995, 52, 289-294. [CrossRef]

83. Oswell, N.J.; Gunstone, F.D.; Pegg, R.B. Vegetable Oils. In Bailey's Industrial Oil and Fat Products; Shahidi, F., Ed.; John Wiley \& Sons, Ltd.: Oxford, UK, 2020; pp. 1-30.

84. Kamal-Eldin, A.; Appelqvist, L.-Å. The chemistry and antioxidant properties of tocopherols and tocotrienols. Lipids 1996, 31, 671-701. [CrossRef] [PubMed]

85. Boskou, D. Olive Oil. In Vegetable Oils in Food Technology; Blackwell Publishing Ltd.: Oxford, UK, 2011 ; pp. $243-271$.

86. Grompone, M.A. Sunflower Oil. In Vegetable Oils in Food Technology; Blackwell Publishing Ltd.: Oxford, UK, $2011 ;$ pp. $137-167$. 
87. Siger, A.; Nogala-kalucka, M.; Lampart-Szczapa, E. The content and antioxidant activity of phenolic compounds in cold-pressed plant oils. J. Food Lipids 2008, 15, 137-149. [CrossRef]

88. Cantrell, A.; McGarvey, D.J.; George Truscott, T.; Rancan, F.; Böhm, F. Singlet oxygen quenching by dietary carotenoids in a model membrane environment. Arch. Biochem. Biophys. 2003, 412, 47-54. [CrossRef]

89. Wang, K.; Zheng, Z.; Liu, C.; Wang, Y.; Li, J.; Liu, Y. Identification and quantification of synergetic antioxidants and their application in sunflower oil. LWT 2020, 118, 108726. [CrossRef]

90. Kumar, K.; Yadav, A.N.; Kumar, V.; Vyas, P.; Dhaliwal, H.S. Food waste: A potential bioresource for extraction of nutraceuticals and bioactive compounds. Bioresour. Bioprocess. 2017, 4, 18. [CrossRef]

91. Maciej, B.; Dimitri, P.M.; Maria-Corina, S.; Amirhossein, S. Editorial: Natural Products as the Integral Part of the Therapy? Curr. Pharm. Des. 2017, 23, 2411-2413. [CrossRef]

92. Lin, C.S.K.; Koutinas, A.A.; Stamatelatou, K.; Mubofu, E.B.; Matharu, A.S.; Kopsahelis, N.; Pfaltzgraff, L.A.; Clark, J.H.; Papanikolaou, S.; Kwan, T.H.; et al. Current and future trends in food waste valorization for the production of chemicals, materials and fuels: A global perspective. Biofuels Bioprod. Biorefining 2014, 8, 686-715. [CrossRef]

93. Pfaltzgraff, L.A.; De bruyn, M.; Cooper, E.C.; Budarin, V.; Clark, J.H. Food waste biomass: A resource for high-value chemicals. Green Chem. 2013, 15, 307-314. [CrossRef]

94. Leong, H.Y.; Chang, C.-K.; Khoo, K.S.; Chew, K.W.; Chia, S.R.; Lim, J.W.; Chang, J.-S.; Show, P.L. Waste biorefinery towards a sustainable circular bioeconomy: A solution to global issues. Biotechnol. Biofuels 2021, 14, 87. [CrossRef] [PubMed]

95. Mak, T.M.W.; Xiong, X.; Tsang, D.C.W.; Yu, I.K.M.; Poon, C.S. Sustainable food waste management towards circular bioeconomy: Policy review, limitations and opportunities. Bioresour. Technol. 2020, 297, 122497. [CrossRef] [PubMed]

96. Viganó, J.; Machado, A.P.d.F.; Martínez, J. Sub- and supercritical fluid technology applied to food waste processing. J. Supercrit. Fluids 2015, 96, 272-286. [CrossRef]

97. Gligor, O.; Mocan, A.; Moldovan, C.; Locatelli, M.; Crișan, G.; Ferreira, I.C.F.R. Enzyme-assisted extractions of polyphenols-A comprehensive review. Trends Food Sci. Technol. 2019, 88, 302-315. [CrossRef]

98. Kumar, K.; Srivastav, S.; Sharanagat, V.S. Ultrasound assisted extraction (UAE) of bioactive compounds from fruit and vegetable processing by-products: A review. Ultrason. Sonochem. 2021, 70, 105325. [CrossRef]

99. Vilkhu, K.; Mawson, R.; Simons, L.; Bates, D. Applications and opportunities for ultrasound assisted extraction in the food industry-A review. Innov. Food Sci. Emerg. Technol. 2008, 9, 161-169. [CrossRef]

100. Mandal, V.; Mohan, Y.; Hemalatha, S. Microwave assisted extraction-An innovative and promising extraction tool for medicinal plant research. Pharmacogn. Rev. 2007, 1,7-18.

101. Villacís-Chiriboga, J.; Vera, E.; Van Camp, J.; Ruales, J.; Elst, K. Valorization of byproducts from tropical fruits: A review, Part 2: Applications, economic, and environmental aspects of biorefinery via supercritical fluid extraction. Compr. Rev. Food Sci. Food Saf. 2021, 20, 2305-2331. [CrossRef]

102. Cheng, Y.; Xue, F.; Yu, S.; Du, S.; Yang, Y. Subcritical Water Extraction of Natural Products. Molecules 2021, 26, 4004. [CrossRef] [PubMed]

103. Durazzo, A.; Lucarini, M.; Kiefer, J.; Mahesar, S.A. State-of-the-Art Infrared Applications in Drugs, Dietary Supplements, and Nutraceuticals. J. Spectrosc. 2020, 2020, 1397275. [CrossRef]

104. Durazzo, A.; Lucarini, M. A current shot and re-thinking of antioxidant research strategy. Braz. J. Anal. Chem 2018, 5, 9-11. [CrossRef]

105. Lucarini, M.; Durazzo, A.; Bernini, R.; Campo, M.; Vita, C.; Souto, E.B.; Lombardi-Boccia, G.; Ramadan, M.F.; Santini, A.; Romani, A. Fruit Wastes as a Valuable Source of Value-Added Compounds: A Collaborative Perspective. Molecules 2021, $26,6338$. [CrossRef]

106. Lucarini, M.; Durazzo, A.; Romani, A.; Campo, M.; Lombardi-Boccia, G.; Cecchini, F. Bio-Based Compounds from Grape Seeds: A Biorefinery Approach. Molecules 2018, 23, 1888. [CrossRef]

107. Lucarini, M.; Durazzo, A.; Lombardi-Boccia, G.; Romani, A.; Sagratini, G.; Bevilacqua, N.; Ieri, F.; Vignolini, P.; Campo, M.; Cecchini, F. Biorefinery for Innovative Production of Bioactive Compounds from Vegetable Biomass. In Biorefinery Production Technologies for Chemicals and Energy; Scrivener Publishing LLC: Beverly, MA, USA, 2020; pp. 89-128.

108. Lucarini, M.; Durazzo, A.; Lombardi-Boccia, G.; Romani, A.; Sagratini, G.; Bevilacqua, N.; Ieri, F.; Vignolini, P.; Campo, M.; Cecchini, F. Case-Studies Towards Sustainable Production of Value-Added Compounds in Agro-Industrial Wastes. In Biorefinery Production Technologies for Chemicals and Energy; Scrivener Publishing LLC: Beverly, MA, USA, 2020; pp. 197-219.

109. Rubió, L.; Motilva, M.-J.; Macià, A.; Ramo, T.; Romero, M.-P. Development of a Phenol-Enriched Olive Oil with Both Its Own Phenolic Compounds and Complementary Phenols from Thyme. J. Agric. Food Chem. 2012, 60, 3105-3112. [CrossRef] [PubMed]

110. Suárez, M.; Romero, M.-P.; Motilva, M.-J. Development of a Phenol-Enriched Olive Oil with Phenolic Compounds from Olive Cake. J. Agric. Food Chem. 2010, 58, 10396-10403. [CrossRef]

111. Suárez, M.; Romero, M.-P.; Ramo, T.; Motilva, M.-J. Stability of a phenol-enriched olive oil during storage. Eur. J. Lipid Sci. Technol. 2011, 113, 894-903. [CrossRef]

112. Delgado-Adamez, J.; Franco Baltasar, M.N.; Ayuso Yuste, M.C.; Martin-Vertedor, D. Oxidative Stability, Phenolic Compounds and Antioxidant Potential of a Virgin Olive Oil Enriched with Natural Bioactive Compounds. J. Oleo Sci. 2014, 63, 55-65. [CrossRef] [PubMed]

113. Suárez, M.; Valls, R.M.; Romero, M.-P.; Macià, A.; Fernández, S.; Giralt, M.; Solà, R.; Motilva, M.-J. Bioavailability of phenols from a phenol-enriched olive oil. Br. J. Nutr. 2011, 106, 1691-1701. [CrossRef] 
114. Chougui, N.; Djerroud, N.; Naraoui, F.; Hadjal, S.; Aliane, K.; Zeroual, B.; Larbat, R. Physicochemical properties and storage stability of margarine containing Opuntia ficus-indica peel extract as antioxidant. Food Chem. 2015, 173, 382-390. [CrossRef]

115. Luo, S.-Z.; Hu, X.-F.; Pan, L.-H.; Zheng, Z.; Zhao, Y.-Y.; Cao, L.-L.; Pang, M.; Hou, Z.-G.; Jiang, S.-T. Preparation of camellia oil-based $\mathrm{W} / \mathrm{O}$ emulsions stabilized by tea polyphenol palmitate: Structuring camellia oil as a potential solid fat replacer. Food Chem. 2019, 276, 209-217. [CrossRef] [PubMed]

116. Şahin, S.; Bilgin, M.; Gülmez, Ö.; Güçlü, K.; Özyürek, M. Enrichment of Hazelnut Oil with Several Polyphenols: An Alternative Approach to A New Functional Food. J. Oleo Sci. 2021, 70, 11-19. [CrossRef]

117. Bakkalbaş1, E. Oxidative stability of enriched walnut oil with phenolic extracts from walnut press-cake under accelerated oxidation conditions and the effect of ultrasound treatment. J. Food Meas. Charact. 2019, 13, 43-50. [CrossRef]

118. Abenoza, M.; Sánchez-Gimeno, A.C. Increasing the stability of Empeltre olive oils by aromatization with rosemary (Rosmarinus officinalis) and garlic (Allium sativum). Int. J. Gastron. Food Sci. 2021, 24, 100333. [CrossRef]

119. Hernández-Hernández, C.; Morales-Sillero, A.; Fernández-Prior, M.Á.; Fernández-Bolaños, J.; Aguilera-Herrera, M.d.l.P.; Rodríguez-Gutiérrez, G. Extra virgin olive oil jam enriched with cocoa bean husk extract rich in theobromine and phenols. LWT 2019, 111, 278-283. [CrossRef]

120. Romeo, R.; De Bruno, A.; Imeneo, V.; Piscopo, A.; Poiana, M. Impact of Stability of Enriched Oil with Phenolic Extract from Olive Mill Wastewaters. Foods 2020, 9, 856. [CrossRef] [PubMed]

121. More, S.B.; Gogate, P.R.; Waghmare, J.S. Bioactives from pomegranate peel and moringa leaves as natural antioxidants for stability of edible oil blends. Braz. J. Chem. Eng. 2021, 1-12. [CrossRef]

122. Mohdaly, A.A.A.; Smetanska, I.; Ramadan, M.F.; Sarhan, M.A.; Mahmoud, A. Antioxidant potential of sesame (Sesamum indicum) cake extract in stabilization of sunflower and soybean oils. Ind. Crops Prod. 2011, 34, 952-959. [CrossRef]

123. Mikołajczak, N.; Sobiechowska, D.A.; Tańska, M. Edible flowers as a new source of natural antioxidants for oxidative protection of cold-pressed oils rich in omega-3 fatty acids. Food Res. Int. 2020, 134, 109216. [CrossRef]

124. Sharma, S.; Cheng, S.-F.; Bhattacharya, B.; Chakkaravarthi, S. Efficacy of free and encapsulated natural antioxidants in oxidative stability of edible oil: Special emphasis on nanoemulsion-based encapsulation. Trends Food Sci. Technol. 2019, 91, 305-318. [CrossRef]

125. Kehili, M.; Choura, S.; Zammel, A.; Allouche, N.; Sayadi, S. Oxidative stability of refined olive and sunflower oils supplemented with lycopene-rich oleoresin from tomato peels industrial by-product, during accelerated shelf-life storage. Food Chem. 2018, 246, 295-304. [CrossRef] [PubMed]

126. Poiana, M.-A. Enhancing Oxidative Stability of Sunflower Oil during Convective and Microwave Heating Using Grape Seed Extract. Int. J. Mol. Sci. 2012, 13, 9240-9259. [CrossRef] [PubMed]

127. Tinello, F.; Lante, A. Accelerated storage conditions effect on ginger- and turmeric-enriched soybean oils with comparing a synthetic antioxidant BHT. LWT 2020, 131, 109797. [CrossRef]

128. Rawson, A.; Patras, A.; Tiwari, B.K.; Noci, F.; Koutchma, T.; Brunton, N. Effect of thermal and non thermal processing technologies on the bioactive content of exotic fruits and their products: Review of recent advances. Food Res. Int. 2011, 44, 1875-1887. [CrossRef]

129. Su, D.; Wang, Z.; Dong, L.; Huang, F.; Zhang, R.; Jia, X.; Wu, G.; Zhang, M. Impact of thermal processing and storage temperature on the phenolic profile and antioxidant activity of different varieties of lychee juice. LWT 2019, 116, 108578. [CrossRef]

130. Nwuha, V.; Nakajima, M.; Tong, J.; Ichikawa, S. Solubility study of green tea extracts in pure solvents and edible oils. J. Food Eng. 1999, 40, 161-165. [CrossRef]

131. Mohanan, A.; Nickerson, M.T.; Ghosh, S. Oxidative stability of flaxseed oil: Effect of hydrophilic, hydrophobic and intermediate polarity antioxidants. Food Chem. 2018, 266, 524-533. [CrossRef]

132. Liu, Y.; Ma, X.; Li, J.; Fan, L.; Huang, S. Study on the antioxidative mechanism of tocopherol loaded ethyl cellulose particles in thermal-oxidized soybean oil. Carbohydr. Polym. 2021, 276, 118734. [CrossRef] [PubMed]

133. Galanakis, C.M.; Tsatalas, P.; Charalambous, Z.; Galanakis, I.M. Polyphenols recovered from olive mill wastewater as natural preservatives in extra virgin olive oils and refined olive kernel oils. Environ. Technol. Innov. 2018, 10, 62-70. [CrossRef]

134. Sánchez-Camargo, A.d.P.; Gutiérrez, L.-F.; Vargas, S.M.; Martinez-Correa, H.A.; Parada-Alfonso, F.; Narváez-Cuenca, C.-E. Valorisation of mango peel: Proximate composition, supercritical fluid extraction of carotenoids, and application as an antioxidant additive for an edible oil. J. Supercrit. Fluids 2019, 152, 104574. [CrossRef]

135. Turan, S.; Köroğlu, D.G. Oxidative stability of soybean oil enriched with ethyl acetate extract of olive by-products. Turk. J. Agric. Food Sci. Technol. 2020, 8, 1373-1379. [CrossRef]

136. Salami, A.; Asefi, N.; Kenari, R.E.; Gharekhani, M. Extraction of pumpkin peel extract using supercritical $\mathrm{CO}_{2}$ and subcritical water technology: Enhancing oxidative stability of canola oil. J. Food Sci. Technol. 2021, 58, 1101-1109. [CrossRef] [PubMed]

137. Velderrain-Rodríguez, G.R.; Salvia-Trujillo, L.; González-Aguilar, G.A.; Martín-Belloso, O. Interfacial activity of phenolicrich extracts from avocado fruit waste: Influence on the colloidal and oxidative stability of emulsions and nanoemulsions. Innov. Food Sci. Emerg. Technol. 2021, 69, 102665. [CrossRef]

138. Sultana, B.; Anwar, F.; Asi, M.R.; Chatha, S.A.S. Antioxidant potential of extracts from different agro wastes: Stabilization of corn oil. Grasas Aceites 2008, 59, 205-217.

139. Mohammadi, A.; Jafari, S.M.; Esfanjani, A.F.; Akhavan, S. Application of nano-encapsulated olive leaf extract in controlling the oxidative stability of soybean oil. Food Chem. 2016, 190, 513-519. [CrossRef] [PubMed] 
140. Garcia-Mendoza, M.d.P.; Espinosa-Pardo, F.A.; Savoire, R.; Harscoat-Schiavo, C.; Cansell, M.; Subra-Paternault, P. Improvement of the oxidative stability of camelina oil by enrichment with phospholipid-quercetin formulations. Food Chem. 2021, $341,128234$. [CrossRef] [PubMed]

141. Ma, X.; Liu, Y.; Fan, L.; Yan, W. Ethyl cellulose particles loaded with $\alpha$-tocopherol for inhibiting thermal oxidation of soybean oil. Carbohydr. Polym. 2021, 252, 117169. [CrossRef]

142. Sayyed-Alangi, S.Z.; Nematzadeh, M. Formulation, development and evaluation of bifunctionalized nanoliposomes containing Trifolium resupinatum sprout methanolic extract: As effective natural antioxidants on the oxidative stability of soybean oil. BMC Chem. 2019, 13, 77. [CrossRef]

143. Hermund, D.; Jacobsen, C.; Chronakis, I.S.; Pelayo, A.; Yu, S.; Busolo, M.; Lagaron, J.M.; Jónsdóttir, R.; Kristinsson, H.G.; Akoh, C.C.; et al. Stabilization of Fish Oil-Loaded Electrosprayed Capsules with Seaweed and Commercial Natural Antioxidants: Effect on the Oxidative Stability of Capsule-Enriched Mayonnaise. Eur. J. Lipid Sci. Technol. 2019, 121, 1800396. [CrossRef]

144. Silva Faria, W.C.; Oliveira, M.G.d.; Cardoso da Conceição, E.; Silva, V.B.; Veggi, N.; Converti, A.; Miguel de Barros, W.; Fernandes da Silva, M.; Bragagnolo, N. Antioxidant efficacy and in silico toxicity prediction of free and spray-dried extracts of green Arabica and Robusta coffee fruits and their application in edible oil. Food Hydrocoll. 2020, 108, 106004. [CrossRef]

145. Taghvaei, M.; Jafari, S.M.; Mahoonak, A.S.; Nikoo, A.M.; Rahmanian, N.; Hajitabar, J.; Meshginfar, N. The effect of natural antioxidants extracted from plant and animal resources on the oxidative stability of soybean oil. LWT-Food Sci. Technol. 2014, 56, 124-130. [CrossRef]

146. Farag, R.S.; El-baroty, G.S.; Basuny, A.M. Safety evaluation of olive phenolic compounds as natural antioxidants. Int. J. Food Sci. Nutr. 2003, 54, 159-174. [CrossRef] [PubMed]

147. Son, T.G.; Camandola, S.; Mattson, M.P. Hormetic Dietary Phytochemicals. NeuroMolecular Med. 2008, 10, 236. [CrossRef]

148. Martin, K.R.; Appel, C.L. Polyphenols as dietary supplements: A double-edged sword. Nutr. Diet. Suppl. 2009, 2, 1-12. [CrossRef]

149. Islam, B.u.; Suhail, M.; Khan, M.K.; Zughaibi, T.A.; Alserihi, R.F.; Zaidi, S.K.; Tabrez, S. Polyphenols as anticancer agents: Toxicological concern to healthy cells. Phytother. Res. 2021, 35, 6063-6079. [CrossRef]

150. Cladis, D.P.; Li, S.; Reddivari, L.; Cox, A.; Ferruzzi, M.G.; Weaver, C.M. A 90 day oral toxicity study of blueberry polyphenols in ovariectomized sprague-dawley rats. Food Chem. Toxicol. 2020, 139, 111254. [CrossRef]

151. Hashempour-Baltork, F.; Torbati, M.; Azadmard-Damirchi, S.; Savage, G.P. Vegetable oil blending: A review of physicochemical, nutritional and health effects. Trends Food Sci. Technol. 2016, 57, 52-58. [CrossRef]

152. Romanić, R.S.; Lužaić, T.Z.; Radić, B.Đ. Enriched sunflower oil with omega 3 fatty acids from flaxseed oil: Prediction of the nutritive characteristics. LWT 2021, 150, 112064. [CrossRef]

153. Tortosa-Caparrós, E.; Navas-Carrillo, D.; Marín, F.; Orenes-Piñero, E. Anti-inflammatory effects of omega 3 and omega 6 polyunsaturated fatty acids in cardiovascular disease and metabolic syndrome. Crit. Rev. Food Sci. Nutr. 2017, 57, 3421-3429. [CrossRef]

154. Golmakani, M.-T.; Soltani, A.; Hosseini, S.M.H.; Keramat, M. Improving the oxidation kinetics of linseed oil using the blending approach. J. Food Process. Preserv. 2020, 44, e14964. [CrossRef]

155. Anwar, F.; Hussain, A.I.; Iqbal, S.; Bhanger, M.I. Enhancement of the oxidative stability of some vegetable oils by blending with Moringa oleifera oil. Food Chem. 2007, 103, 1181-1191. [CrossRef]

156. Bordón, M.G.; Meriles, S.P.; Ribotta, P.D.; Martinez, M.L. Enhancement of Composition and Oxidative Stability of Chia (Salvia hispanica L.) Seed Oil by Blending with Specialty Oils. J. Food Sci. 2019, 84, 1035-1044. [CrossRef] [PubMed]

157. Kaseke, T.; Opara, U.L.; Fawole, O.A. Blending of Sunflower Oil with Pomegranate Seed Oil from Blanched Seeds: Impact on Functionality, Oxidative Stability, and Antioxidant Properties. Processes 2021, 9, 635. [CrossRef]

158. Mariod, A.; Matthäus, B.; Eichner, K.; Hussein, I.H. Improving the oxidative stability of sunflower oil by blending with Sclerocarya birrea and Aspongopus viduatus oils. J. Food Lipids 2005, 12, 150-158. [CrossRef]

159. Bhatnagar, A.S.; Prasanth Kumar, P.K.; Hemavathy, J.; Gopala Krishna, A.G. Fatty Acid Composition, Oxidative Stability, and Radical Scavenging Activity of Vegetable Oil Blends with Coconut Oil. J. Am. Oil Chem. Soc. 2009, 86, 991-999. [CrossRef]

160. Rudzińska, M.; Hassanein, M.M.; Abdel-Razek, A.G.; Ratusz, K.; Siger, A. Blends of rapeseed oil with black cumin and rice bran oils for increasing the oxidative stability. J. Food Sci. Technol. 2016, 53, 1055-1062. [CrossRef] [PubMed]

161. Kiralan, M.; Ulaş, M.; Özaydin, A.; Özdemır, N.; Özkan, G.; Bayrak, A.; Ramadan, M.F. Blends of Cold Pressed Black Cumin Oil and Sunflower Oil with Improved Stability: A Study Based on Changes in the Levels of Volatiles, Tocopherols and Thymoquinone during Accelerated Oxidation Conditions. J. Food Biochem. 2017, 41, e12272. [CrossRef]

162. Nadeem, M.; Imran, M.; Iqbal, Z.; Abbas, N.; Mahmud, A. Enhancement of the Oxidative Stability of Butter Oil by Blending with Mango (Mangifera indica L.) Kernel Oil in Ambient and Accelerated Oxidation. J. Food Process. Preserv. 2017, 41, e12957. [CrossRef]

163. Torri, L.; Bondioli, P.; Folegatti, L.; Rovellini, P.; Piochi, M.; Morini, G. Development of Perilla seed oil and extra virgin olive oil blends for nutritional, oxidative stability and consumer acceptance improvements. Food Chem. 2019, 286, 584-591. [CrossRef]

164. Rodríguez, G.; Villanueva, E.; Cortez, D.; Sanchez, E.; Aguirre, E.; Hidalgo, A. Oxidative Stability of Chia (Salvia hispanica L.) and Sesame (Sesamum indicum L.) Oil Blends. J. Am. Oil Chem. Soc. 2020, 97, 729-735. [CrossRef]

165. Garg, M.; Wason, S.; Meena, P.L.; Chopra, R.; Sadhu, S.D.; Dhyani, A. Effect of frying on physicochemical properties of sesame and soybean oil blend. J. Appl. Nat. Sci. 2021, 13, 820-829. [CrossRef]

166. González-Gamallo, S.; Salvador, M.D.; Fregapane, G. Design and Characteristics of Novel Sensory and Nutritionally Oriented Olive, Seed, and Nut Virgin Oils' Blendings. Eur. J. Lipid Sci. Technol. 2021, 123, 2100008. [CrossRef] 